Portland State University

PDXScholar

$11-21-2020$

\title{
Examining the U.S. Wars on Vietnam, Laos, and Cambodia as the Production of Neo-Colonialism
}

\author{
Aiden Gregg \\ Portland State University
}

Follow this and additional works at: https://pdxscholar.library.pdx.edu/honorstheses

Part of the Feminist, Gender, and Sexuality Studies Commons, Holocaust and Genocide Studies Commons, and the Race, Ethnicity and Post-Colonial Studies Commons Let us know how access to this document benefits you.

\section{Recommended Citation}

Gregg, Aiden, "Examining the U.S. Wars on Vietnam, Laos, and Cambodia as the Production of NeoColonialism" (2020). University Honors Theses. Paper 958.

https://doi.org/10.15760/honors.982

This Thesis is brought to you for free and open access. It has been accepted for inclusion in University Honors Theses by an authorized administrator of PDXScholar. Please contact us if we can make this document more accessible: pdxscholar@pdx.edu. 
Examining the U.S. Wars on Vietnam, Laos, and Cambodia as the Production Neo-Colonialism

by

\title{
Aiden Gregg
}

\begin{abstract}
An undergraduate honors thesis submitted in partial fulfillment of the requirements for the degree of

Bachelor of Science

in

University Honors

and

Sociology
\end{abstract}

Thesis Adviser

Julius McGee

Portland State University

2020

Gregg 1 
Table of Contents

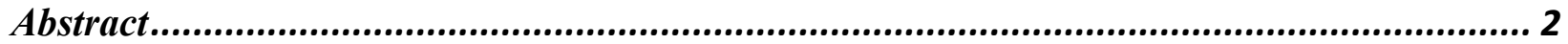

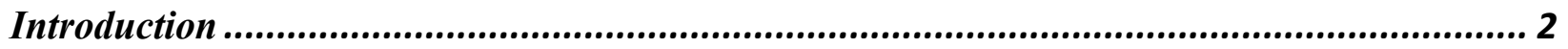

Theoretical Background .................................................................................................... 7

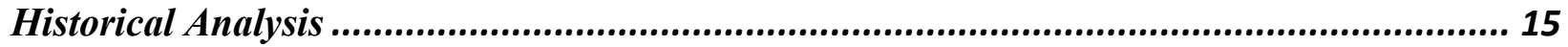

Hierarchy, Labor, and Violence under French colonization................................................................. 18

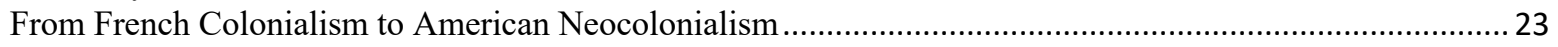

Chemical Warfare, Disability, and the Green Revolution .............................................................................. 27

Weaponizing Primarily white male Rage and Rape as Standard Operating Procedure................................... 31

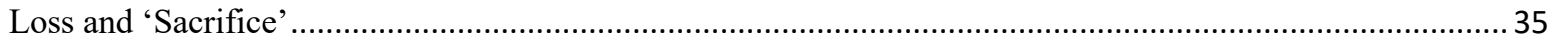

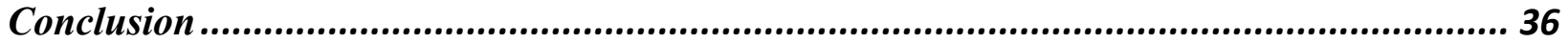

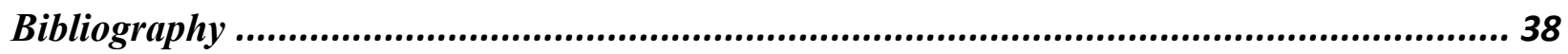

Abstract

I interrogate the colonial and neo-colonial histories of the U.S. wars on Vietnam, Cambodia, and Laos within the context of racialized and gendered labor accumulation, the production of difference through violence as a legitimation of colonial extraction, and ongoing neoliberal economic coercion. I examine genocide and ecocide as interdependent processes in the production of dependency and underdevelopment. I reject a common narrative of temporal and spatial disconnection which separates the wars from current economics and examine the violences which both produce and result from an economy based on growth.

\section{Introduction}

Over the past few decades, following the 1986 Đổi Mới economic reforms, a key aim of some imperially/capitally aligned news outlets in the portrayal of the 'opening' of the Vietnamese economy has been to praise and naturalize the policies, present them as something that has occurred simply because capitalism is good and evolutionary and rational, a result of the failures of communism and proof that communism cannot be implemented. Parallel to this is a construction of the war on Vietnam as a historical fault, a really bad idea, a blunder, a blemish on the image of America, old news, history. A modern ahistoricity matched with curated historical accounts which disconnect genocide and ecocide from current economics, exploitation, and expropriation.

One prime example of this is Thomas Fuller's New York Times article "Capitalist Soul Rises as Ho Chi Minh City Sheds Its Past". 'Fuller talks to a few rich outliers, among them a millionaire tech entrepreneur, a Canadian market research manager, and a man who took over his parent's real estate company and now owns four businesses, relaying their conversations about how great being rich is as proof that actually, capitalism is fantastic.

Fuller writes:

"If, for the Americans, the war here, in which 58,000 Americans and as many as three million Vietnamese died, was on some level about keeping Vietnam safe for capitalism, it turns out that they need not have worried. Capitalism here churns relentlessly, aided by what Ted Osius, the United States ambassador, calls "the most entrepreneurial people on earth." 
In writing that the war was about "keeping Vietnam safe for capitalism." Fuller implicitly recognizes that the war was about creating a future in which capitalists could exploit and expropriate the labors of Vietnam, while spinning this as protective rather than genocidal. Then, he leans into the narrative of loss, as if to say 'remember guys, this totally wasn't our goal, wink', with 'it turns out they need not have worried." Fuller utilizes a common narrative of loss which disconnects time as if space doesn't exist and as if the two are unrelated. In part by this I mean it claims the war ended at unification, thereby both ignoring how the material aspects of war function, from the massive herbicidal campaigns to the disabling of millions of people to the destruction of infrastructure, and on, and ignoring how the U.S. continued to wage war against Vietnam both economically, and through the backing of other groups post-war including the Khmer Rouge. By saying we lost in 1975 is to whitewash all forms warfare after that point, and by acting as if the material aspects of the war prior had no impact on the nation post reunification, Fuller is able to portray communism as a "disastrous" failure without analyzing the neo-colonial capitalist production of failure. Essentially, he says we were making capitalism, and that was good and not something to critically interrogate, but we lost, but luckily because communism sucks and because of some weird racial construction of some Vietnamese as "entrepreneurs" and nothing at all to do with us, capitalism still happened.

Which begs the obvious question, if the policies were going to fail regardless of context, then why did Dulles, Eisenhower, and the U.S. throw their weight behind Diệm when he refused to follow through on the agreed upon democratic elections? Why spend $\$ 141$ billion ${ }^{2}$ over two decades subsidizing the murder of 3.8 million people ${ }^{3}$, the disabling, rape, and displacement of millions more, as well as countless other atrocities? But of course, I'm overthinking this. Not the genocide and ecocide, or its relation to neocolonialism but the New York Times fluff piece which essentially boils down to 'Pull yourself up by the bootstraps like these totally down to earth millionaires!' The piece isn't meant to provide material analysis, it's meant to distract from it.

This is true of many narratives of the war on Vietnam in American media. Narratives frequently center the experiences of white men sent to war, while dehumanizing the people they murder on screen. In an essay responding to Spike Lee's Da 5 Bloods, a rare representation of the war focused on Black veterans, Viet Thanh Nguyen explains the formulaic racism of Hollywood interpretations of the war on Vietnam as such:

"For Americans, Hollywood turns a defeat by Vietnamese people into a conflict that is actually a civil war in the American soul, where Americans' greatest enemies are actually themselves. In one of the stranger twists in self-aggrandizement, Hollywood renders Americans as the antiheroes, which might seem odd given that Hollywood is America's unofficial ministry of propaganda.

The reason for this troubling treatment is simple: For Hollywood, and for Americans, it is better to be the villain or antihero rather than virtuous extra, so long as one occupies center stage. For Vietnamese people, as well as Laotians, Cambodians and Hmong, their role is almost always that of the extra, their function: to be helpful, rescued, blamed, analyzed, mocked, abused, raped, killed, spoken for, spoken over, misunderstood or all of the above."

Nguyen identifies the erasure of Black narratives in film while arguing that:

“"Da 5 Bloods' clearly aspires to be a movie that jabs at American racism and imperialist warmongering, but whereas it succeeds at the former, it fails at the latter. Why? In putting Black subjectivity at the center, Lee also continues to put American subjectivity at the 
center. If one can't disentangle Black subjectivity from dominant American (white) subjectivity, it's impossible to apply a genuine anti-imperialist critique. Hence the marginalized Vietnamese continuing to serve their role as excuses for a Black drama staged against America's Black-white divide.

This is not an argument for more Vietnamese inclusion. It's a demand that we recognize how decolonization and anti-imperialism are impossible if we keep reiterating the imperial country's point of view, even from the minority perspective."4

He also comments on one scene as an example of the presentation of perpetual Vietnamese victimhood, and identifies the dissonance between the exaggerated emotions of the scene and the reality of visiting Vietnam, saying:

"Many American visitors to Vietnam remark in amazement that the Vietnamese have seemed to let the past go. This is true. We have no time to hate Americans because we hate each other more, given that our war was actually a civil war (plus, the Vietnamese really hate the Chinese the most). The Americans and the French, our former colonizers, are seen as walking wallets, not to be offended."

The war was, as he says, undoubtably a civil war, and the American invaders were, as he says, colonizers. And, to be very clear, I am absolutely nitpicking in this next point, not to criticize the article or the framing of this in the article, but to grasp at a broader collective narrative that I (perhaps wrongly) believe obscures the ongoing harms of capitalism and how those are tied to the neocolonialism of the war. Specifically, the narrative not just that the war is past but that colonization (at least in terms of American and French colonization) is past. Are Vietnam, Cambodia, and Laos neocolonial states?

Ghanaian revolutionary and first Prime Minister and President of Ghana, Kwame Nkrumah, articulated the theory of the neo-colonial state, wherein the colony achieves a "certain area of maneouvre" in the form of a formal separation from the former colonizing state, but is dependent upon aid regimes, loans, and foreign capital, which are used to further exploitation. He identifies a potential path away from colonial control in the form of non-alignment and multi-lateral aid, wherein the goal of the state is "not aimed at excluding the capital of the developed world from operating in less developed countries. It is aimed at preventing the financial power of the developed countries being used in such a way as to impoverish the less developed." All three countries have committed to the Non-Aligned Movement, Cambodia in 1961, Laos in 1964, and Vietnam in 1976 following reunification. But does official non-alignment translate to being outside of neo-colonial control? Or perhaps, rather than asking if these states 'are' neo-colonial states, instead how does a Colonial/Modern (to draw upon Lugones and Quijano's work) globalized capitalism affect these states, and how does this relate to legacies of colonization?

Although for the past few decades poverty has been declining in all three countries ${ }^{678}$, economic inequality is rising in all three as well ${ }^{9}{ }^{10}$. Cambodia holds $\$ 13.346$ billion US (about half of its GDP) in external debt. ${ }^{11}$ A neoliberal "debt economy" 12 , as Sylvia Federici calls it, has replaced colonial debt slavery with microloan debt. In Cambodia, this has produced a set of crises which has been "compounded"13 by the coronavirus. In an article for Reuters, Mech Dara and Matt Blomberg talk to Set Sreylon about her experiences with microfinance loans:

"With the coronavirus pandemic ending Sreylon and her husband's jobs in the tourism industry, the mother-of-two was at a loss as to how she would keep the lenders at bay, and clear a growing debt secured by the title to her family's land. Her debt - originally a single loan from a microfinance institution (MFI) - had almost doubled in a year to $\$ 8,000$ and was pursued by various loan sharks charging up to $40 \%$ interest. 'You borrow from A to pay B, 
then you borrow from B to pay C,' she said outside her home in Pouk district, a few miles from Cambodia's Angkor temples and the tourism hotspot of Siem Reap. 'What's the end result? You run out of letters and you have to sell your land,' ... She holds one of 2.7 million microloans in a country of 3.3 million households, where the average debt per borrower is the world's highest at $\$ 3,800$ - more than twice Cambodia's gross domestic product per capita....About $45 \%$ of Cambodians fell deeper into debt from January to April, while one in eight had to sell assets, from livestock and machinery to land, according to a survey of 54 village chiefs and 1,000 households by consultancy firm Angkor Research. A third of new loans were taken to pay off existing loans or cover living costs, while the proportion of households that borrowed from informal lenders rose to $18 \%$ from $8.6 \%$ in that period, showed the data, which covered five of 25 provinces." In 2018, Cambodia received $\$ 546.01$ million in net Official Development Aid according to the OECD. ${ }^{14}$ In 2020, the U.S. provided Cambodia with $\$ 56$ million in aid ${ }^{15}$, and an extra $\$ 100,000$ following flash flooding ${ }^{16}$. The floods, which have caused the deaths of dozens of people and impacted over 130,000 families, are a result not only of intensifying weather events but of the rapid 'development' of land around Phnom Penh, specifically the destruction of natural flood barriers. Shaun Turton and Mech Dara write "since 2003, developers of satellite cities and gated housing communities have filled more than $60 \%$ of the city's lakes and more than $40 \%$ of its major wetland areas." ${ }^{17}$ In 2018, textiles and footwear accounted for $78.4 \%$ of all of Cambodia's exports, totaling $\$ 15.36$ billion. The United States was its biggest single export market, receiving $19.3 \%$ of exports. Europe combined accounts for $45.3 \%$ of its exports. ${ }^{18}$ Over $60 \%$ of the garment factories in Cambodia are around Phnom Penh. ${ }^{19}$ The urbanization, (and related ecological destruction/harmful impacts on people) of Phnom Penh should be viewed in the context of industrialization and neocolonial capitalism.

Laos holds $\$ 15.587$ billion US in external debt (nearly $80 \%$ of its GDP), and received $\$ 376.02$ million in net Official Development Aid disbursements in 2018. Partially due to the drop in tourism during coronavirus, Laos is now facing debt default, with its foreign reserves falling below it's annual $\$ 1$ billion debt obligation. ${ }^{20} 45 \%$ of Laos debt is owed to China, largely in relation to the Belt and Road Initiative. ${ }^{21}$ Laos is currently in talks with China to write off or renegotiate payments. Given that coronavirus shocks are causing difficulty with debt repayment in many of the countries who owe China and given the widespread pressure on China to cancel or renegotiate debt payments, it seems likely that this will happen ${ }^{22}$. This seems as good a time as any to clarify, before I continue: Given how the U.S. has been dramatically escalating sanctions, sinophobic rhetoric, and military propaganda, attempting to manufacture consent for either 'hot' or 'cold' war with China, I want to say clearly that any criticisms I have around, for instance, the impacts of the BRI, do not match the impacts of the U.S. military, which should be abolished in its entirety. As I hope to show later in this thesis, the power imbalances between China and Laos, for example, have been largely exacerbated by U.S. and French colonialism, as well as capitalism, and any solution to those power imbalances depends upon abolishing the neocolonial capitalist mode of production, which includes the dismantling of related violent institutions.

Laos is leaning heavily into these mega-projects, most of which are related to the exportation of power-- both the delivery of power, and the production of it, including many 'sustainable' markets such as wind and solar power. Electricity is Laos' largest export, making up 27.7\% of total exports ${ }^{23}$. As of April 2019, Laos had 57 power plants including 49 hydrodams generating $36,935.23 \mathrm{GWh}$ yearly, out of which 6,287 million $\mathrm{kWh}$ is locally consumed. ${ }^{24}$ 
Cambodia has also been building mega-hydrodams over the past few decades. However, as of March 2020, Cambodia has postponed projects for a decade to prevent further damage to the Mekong river biodiversity ${ }^{25}$. The construction of mega-project hydrodams is an exceptionally ecologically destructive process. As Moran et al. report:

"Sharp declines in available freshwater due to dam construction drive seasonal changes in river discharge as well as loss of downstream freshwater habitat, floodplains, and even coastal erosion and salinity changes (23-26). The negative consequences for ecosystem structure and composition (e.g., habitat fragmentation, loss of aquatic and terrestrial biodiversity) and function (e.g., nutrient flows, primary production) can be severe (7,8, 19). Reservoirs can also be significant sources of greenhouse gases, especially methane $(10,23,27-30)$, and their reductions in river flow can increase pollutant concentrations $(31,32)$. The human costs of large dams are no less important. The social, behavioral, cultural, economic, and political disruptions that populations near dams face are routinely underestimated.... A report of the world Commission on Dams (WCD) (37) documented the socioeconomic problems due to dam development projects; 40-80 million people were displaced, and it has proven challenging to resettle them properly. ...In addition, the living conditions and food security of communities living downstream are often placed in peril." (p. 11892) ${ }^{26}$

Like Cambodia and Vietnam, Laos has been heavily impacted by the October floods, the most recent round of annually intensifying flood events. Because of its produced dependence on China, despite rising awareness of the damages mega-projects like these dams can do, despite Cambodia's decision to halt dam construction (for now), Laos is doubling down on these projects.

Vietnam holds $\$ 108.096$ billion US in external debt (about 44\% of its GDP), and received \$777.98 million in net Official Development Aid disbursements. Of its \$274 billion in 2018 exports, $41.8 \%$ went to either Europe or North America. China was its biggest single market, at $19.6 \%$, with the U.S. right behind at $18.1 \%{ }^{27}$ As Milford Bateman outlines, unlike Cambodia, Vietnam has implemented a microfinance system which has effectively achieved the aims promised by the microfinance boom, by doing what the dominant ideologies of microfinancing reject. ${ }^{28}$ Namely, Vietnam's MFIs are public or semi-public entities, they don't borrow to fund or give large salaries and bonuses to employees, and they have significantly lower interest rates than most other MFIs.

As Bateman writes: 'In the context of the UN's Millennium Development Goal of halving extreme poverty in the period of 1990-2015, Vietnam's progress in reducing the poverty rate by 2004 to one third of its 1993 level is simply astonishing. At least partly, this progress has been achieved by ensuring a very pro-poor economic policy - the Gini coefficient rose only from 0.34 in 1993 to 0.36 in 2006." (p. 191) However, as Vu Thi Quynh Hoa and Andrew Wells-Dang report for the UN Research Institute for Social Development, over the past decade and a half inequality has risen quickly in Vietnam. "Vietnam's 210 super-rich individuals (with assets of over USD 30 million) now earn enough in one year to lift 3.2 million people out of poverty" To put this in perspective, however, of the 265,490 super-rich in the world (who have violently accumulated a total of \$32.3 trillion dollars), half of them live in North America, with 8,980 in New York City alone. ${ }^{29}$

Vietnamese upward mobility is on the decline, and workers are underpaid and overworked. A Fair Labor Association report involving almost 13,000 workers found "Those workers who earn an adequate wage can do so only through long hours and excessive days of work without 
rest, in clear violation of international standards. While all of the regional legal minimum wages in Vietnam fall well above the World Bank Poverty line, none meet even the lowest living wage benchmark." (p. 11) ${ }^{30}$ Wildcat strikes against dangerous or unsustainable working conditions have been and continue to be exceptionally common since the $90 \mathrm{~s}$, in part due to the unreliability of formal unions with regards to bettering conditions. In the first five months of 2020 alone there were 91 , responding to mass layoffs and hour cuts during the spreading pandemic. ${ }^{31}$

Nkrumah wrote:

"Neo-colonialism is the victim of its own contradictions. In order to make it attractive to those upon whom it is practised it must be shown as capable of raising their living standards, but the economic object of neo-colonialism is to keep those standards depressed in the interest of the developed countries. It is only when this contradiction is understood that the failure of innumerable 'aid' programmes, many of them well intentioned, can be explained."

As demonstrated, an example of this contradiction can be seen in the UN's Development Goals, where assimilation into exploited wage labor is seen as "reducing poverty," and profit-driven food distribution which accounts for the simultaneous overproduction of food and increasing global malnourishment (690 million people ${ }^{32}$ ) is given as a recommendation for alleviating hunger. The 2015-2030 Sustainable Development Goals are of particular note because of their capitalist co-optation of ecological concern. While global warming, deforestation, ocean acidification, intensifying weather events, pollution, soil fertility decline, and loss of biodiversity are all matters of extreme urgency, they also are the result of a capitalist mode of production and colonialism. Overproduction, and production for profit, are inherently unsustainable, and the commitment to these power dynamics represents a commitment to retaining colonial power dynamics while, like colonial dynamics always have, determining whose deaths do not matter to the accumulators.

In the next section of this thesis, I aim to examine the conceptual structures of colonial capitalist domination and accumulation. I engage with theoretical frameworks and histories from the Black radical tradition, feminist Marxisms, decolonial studies, and ecofeminism. In the section after that, I present an incomplete account of the interdependently genocidal and ecocidal colonization and neo-colonization of what are now known as Cambodia, Laos and Vietnam. In the conclusion, I reinforce the need to work towards the abolition of the military and police state, prisons, the capitalist mode of production, debt, and borders.

\section{Theoretical Background}

Cedric Robinson, in his book Black Marxism, follows, exposes, and constructs a history of the Black radical tradition, built by those in the African diaspora in resistance to the violences of racial capitalism, through trauma and survival, and out of situated cultural knowledges. ${ }^{33}$ Robinson traces a genealogy of racial, labor, and nation constructions originating in Europe and how these shift/expand/morph with colonization, mercantilism, and industrialization. He examines how Christianity, in a twisted symbiosis with Italian capitalism, spread not only racism but holy justification for violent racist expropriation and exploitation. Further, Robinson explores how European movements offering alternatives to capitalism also were grounded in Eurocentric and whitewashed constructions of history, race, and knowledge. Robinson writes that 
"Marx had meant by primitive accumulation that the piezas de Indias had been produced, materially, and intellectually, by the societies from which they were taken and not by those by which they were exploited. The cargoes of the slave ships were real human beings, notwithstanding their manner of transport, the bills of ladino, the captains' logs and trade account books that designated them otherwise.

However, Marx had not realized fully that the cargoes of laborers also contained African cultures, critical mixes and admixtures of language and thought, of cosmology and metaphysics, of habits, beliefs, and morality. These were the actual terms of their humanity. These cargoes, then did not consist of intellectual isolates or deculturated Blacks - men, women, and children separated from their previous universe. African labor brought the past with it, a past that had produced it and settled on it the first elements of consciousness and comprehension." (p. 121-122)

In his article Coloniality of Power and Eurocentrism in Latin America, Aníbal Quijano examines how global racial capitalist labor hierarchies result from both "the expansion of colonial domination by a single 'race' of the rest of the world's population over the last 400 years" and the American "success" in imposing a both a "racist distribution of social identitites" and "racist distribution of forms of work and exploitation... Above all, 'Whiteness' was associated almost exclusively with a salary and, of course, with commanding posts of colonial administration." 34 (pg. 217) Quijano and Robinson each argue that capitalism is neither a rejection of nor merely an evolution from feudalism, and that the Eurocentric moralistic evolutionary arguments aim to conceal the ongoing dependence on the expropriation of labor through enslavement. Quijano writes:

"From the European point of view, reciprocity, slavery, serfdom, and the independent production of commodities are all perceived as a historical sequence prior to commodification of labor force or capital, and they are considered to be not just different but radically incompatible with the latter. The fact is, however, that none of them were in America, solely an extension of the ancient forms, nor were they incompatible with capital. Quite the contrary. So slavery was deliberately established and organized as a commodity to produce commodities of the world market, that is to say, to serve the purposes and necessities of capitalism, and it was structurally articulated with one specific 'race'." (p. 218)

He continues, elucidating the specific context of settler colonization of America:

"Before the developments in America, nowhere was there a system that was structurally articulated to all other forms of organizing and controlling labor force and work, nor had any already a large predominance. It could only be consolidated and win world predominance with America, precisely as the axis around which all other forms were articulated; in other words, only as a central part of capitalism. So capital existed long before America. But capitalism came into history, for the first time, with America. And from then on, and at a world scope, capital has always existed and exists today as the central axis of capitalism.

He then explains how the Castilian colonizers erased the "histor[ies], language[s], achievement[s], memor[ies], and identit[ies]," of the "Aztecs, Mayas, Quechuas, Aymaras, Incas, Chibchas, and others," as well as those of "the people brought as slaves: Ashantis, Yorubas, Zulus, Congos, Bacongos, and others" though the application of "racial" identity." He writes 
"All of the dominated peoples had been deprived of their own historic identities." (p. 219)

Quijano expands upon this hierarchical consolidation/erasure, explaining that

"And it was Western Europe that termed that knowledge perspective 'modernity' and 'rationality'... One of the key elements of this Western European version of modern rationality was a mutation of the old dualist way of looking at the universe. Above all, this changed the relations between 'Body' and 'non-Body' ('subject', 'spirit' or 'reason'), and between Europe and non-Europe. In both fields, the European or Eurocentric version of modernity/rationality implicated real novelty. First, unlike in all non-western imaginaries, after Descartes, 'body' was simply forgotten as a necessary component of the idea of human or person. In that version, 'body' was installed in rational knowledge as a lower status 'object' of study. It is only the 'subject' that counts, as the protagonist of cogito, since 'subject', 'spirit' or 'reason' are but secularizations of 'soul'. Second, the relations between European and non-European suffered a temporal altercation: all nonEurope belonged to the past, and so it was possible to think about relations between them in an evolutionary perspective.

Without the expulsion of 'body' from the realm of spirit through its 'objectification', the pretension of 'scientific' or 'theoretical' elaboration of the idea of 'race' during the following centuries, especially in the $19^{\text {th }}$ century (Gobineau), hardly could have been possible: the 'inferior' 'races' are 'inferior' because they are 'objects' of study or of domination/exploitation/discrimination, they are not 'subjects', and most of all, they are not 'rational subjects'. Thus, they could legitimately be dominated and exploited. And only from that peculiar point of view was it ('rationally') possible to consider all nonEuropean peoples as the past as previously articulated: as objects of knowledge or of domination and exploitation by Europeans. All of it gave way to an evolutionist historical perspective, so that all non-europeans could be placed vis-à-vis Europeans in a continuous historical chain from 'primitive' to 'civilized', from 'irrational' to 'rational', from 'traditional' to 'modern', from 'magic-mythic' to 'scientific'; in sum, from noneuropeans to something that could be, in time, at best Europeanized or 'modernized'." (p. 221)

Quijano's exploration of the Eurocentric knowledge construction of body/mind dualism as an evolutionary timeline is distinctly set up to be expanded into specific interpretation along various hierarchical intersections. This is similar to Patricia Hill Collins' construction of a matrix of domination, in which one's experiences are uniquely dependent upon the intersections of one's privileges and oppressions. ${ }^{35}$ Collins' matrix of domination is in discourse with Kimberle Crenshaw's theory of intersectionality, which states that people experience oppression differently based on their specific positionality within intersecting hierarchies, and that conceptualizations of marginalized groups will presume the marginalized to be the most privileged of the broader marginalized group - for example discussions of the oppression of women center wealthy white cis able-bodied heterosexual thin women. ${ }^{36}$

"Modernizing" narratives of disability construct and imply fictive pasts in which disabled people were simply discarded, killed, uncared for, or unaccommodated in opposition to "modernity" defined by the assimilation of disabled people into colonial healthcare institutions, formal acknowledgement of rights for disabled people as a sign of progress, accompanied by a goal of declining disability. The Colonial/Modern perceived utopia is a world without disabled people, which is not meant to be a replacement of disabling institutions or spatial construction 
(as that would require a dismantlement of the colonial capitalist structures), but rather a white supremacist belief in racialized, mental and bodied purity. The body is a made into a site of determining and creating perceptions of superiority/inferiority and acceptable violence. This narrative of time also serves to whitewash the pharmaceutical colonialism which interchangeably appropriate, commodify, and suppress indigenous knowledges depending on profitability or perceived threats to hierarchical oppression.

The determination of acceptable violence and death, and more specifically the "sovereign right to kill" is one described by Achille Mbembe in his theory of necropolitics. ${ }^{37}$ In many ways colonial capitalist systems intentionally disable people - through police and military brutality, through corporate pollution and the effects of ecocide and extraction on increasingly destructive weather events, through infrastructural inaccessibility, degradation, and austerity, through expensive racist, sexist, fatphobic, ableist gatekept healthcare which dismisses people's knowledge of their own bodies, and on and on. The fictive temporal construction of non-Europe as past and Europe as present is mirrored in split, racialized, classed healthcare. Further, as Harriet Washington's research in Medical Apartheid has shown, colonial healthcare systems are built for wealthy white men and secondarily wealthy white women, through the disabling of and experimentation on Black bodies. ${ }^{38}$

For the Capitalist, disability is a specter and a scapegoat, a threat and excuse for the poor conditions of workers. The state blames manufactured scarcity of accessibility on disabled people. Able bodied workers are taught to resent disabled people, who they are taught are 'lazy' and 'not working'. This actually conceals the significant amount of reproductive healthcare labor that disabled people and their frequently unpaid caretakers have to do, overwhelmingly without the help of healthcare services because of the inaccessibility, gatekeeping, gaslighting, and cost of those services. Further, colonial capitalist constructions of worth center on profitability, and make rights contingent upon a wage, so 'progressive' discussions in these institutions primarily center on assimilating disabled people into the workplace, rather than ensuring people have what they need regardless of how much of their labor capitalists can steal. These discussions also conceal that the constructions of disabled people as 'unproductive' are directly related to the suppression of disabled people's wages, and that programs designed to assimilate disabled people into workspaces frequently pay disabled workers less than their abled counterparts. The spatial/temporal disassociation of "modern" from "primitive" allows for a façade of modern capitalism not relying on enslaved and expropriated labor. In the context of disability, this means hiding both the expropriation of social reproductive labor and devaluing disabled peoples labor to increase profit margins. When the state coopts/assimilates the work of disability rights activists, it does so under the guise of progression, decoupling the rights demanded from the legacies of genocide and ecocide which create both disability itself and the oppression of disabled people.

These are directly related to the expropriation of feminized labors, legitimated by a coloniality of gender and sexuality, as described by María Lugones in Heterosexualism and the Colonial/Modern Gender System. Lugones builds on Quijano and Collins' work, identifying how colonization imposed upon the colonized new racialized systems of gender and sexuality, in relation to but not the same as European gender systems, through gendered and sexualized violence, bureaucratic systems offering relative privilege to those perceived as cisgender heterosexual men, and translation/language. Lugones references Oyéronké Oyewùmí's work The Invention of Women, examining the imposition of categorical gender separation on the Yoruba society: 
"In The Invention of Women, Oyéronké Oyewùmí raises questions about the validity of patriarchy as a valid transcultural category $(1997,20)$. She does so, not by contrasting patriarchy and matriarchy, but by arguing that "Gender was not an organizing principle in Yoruba society prior to colonization by the West" (31). No gender system was in place. Indeed, she tells us that gender has "become important in Yoruba studies not as an artifact of Yoruba life but because Yoruba life, past and present, has been translated into English to fit the Western pattern of body-reasoning" (30). The assumption that Yoruba society included gender as an organizing principle is another case "of Western dominance in the documentation and interpretation of the world, one that is facilitated by the West's global material dominance" (32). She tells us that "researchers always find gender when they look for it" (31). "The usual gloss of the Yoruba categories obinrin and okunrin as 'female/woman' and 'male/man', respectively, is a mistranslation. These categories are neither binaries opposed nor hierarchical” (32-33). The prefixes obinrin and okunrin specify a variety of anatomy. Oyewùmí translates the prefixes as referring to the anatomic male and the anatomic female, shortened as anamale and anafemale. It is important to note that she does not understand these categories as binaries opposed. Oyewùmí understands gender as introduced by the West as a tool of domination that designates two binaries opposed and hierarchical social categories. 'Women' (the gender term) is not defined through biology, though it is assigned to anafemales. Women are defined in relation to men, the norm. Women are those who do not have a penis; those who do not have power; those who cannot participate in the public arena (Oyewùmí 1997, 34). None of this was true of Yoruba anafemales prior to colonization.

'The imposition of the European state system, with its attendant legal and bureaucratic machinery, is the most enduring legacy of European colonial rule in Africa. One tradition that was exported to Africa during this period was the exclusion of women from the newly created colonial public sphere... The very process by which females were categorized and reduced to "women" made them ineligible for leadership roles... The emergence of women as an identifiable category, defined by their anatomy and subordinated to men in all situations, resulted, in part, from the imposition of a patriarchal colonial state. For females, colonization was a twofold process of racial inferiorization and gender subordination. The creation of "women" as a category was one of the very first accomplishments of the colonial state. It is not surprising, therefore, that it was unthinkable for the colonial government to recognize female leaders among the peoples they colonized, such as the Yorùbá...The transformation of state power to Male-gender power was accomplished at one level by the exclusion of women from state striations. This was in sharp contrast to Yoruba state organization, in which power was not gender-determined. (123-25)"'

Barbara Omolade explains how the production by wealthy land and slave owning white men of an expandable and patriarchal construct of whiteness during early colonial United States settlement functioned to legitimate the expropriation of racialized and gendered labor:

"Ultimately, white men were politically empowered to dominate all women and all black men and women; this was their sexual freedom.

From the beginning, the founding fathers assumed the patriarchal right to regulate and define the sexual behavior of their servants and slaves according to a fusion of Protestantism, English Common Law, and personal whim. During the early colonial period 
the distinctions between indentured servant and slave were blurred and relative: most workers, black and white, male and female, worked without direct payment or without control over their labor. These laborers shared enough common experiences to jointly attack their masters and to have sex with each other. The master's racial attitudes of antipathy toward black people and his fears of a unified antagonistic force of all workers, including Indian women and men, demanded that the category "white" be expanded to give political power and freedom to all white men (theoretically and potentially, if not at that historical time) and patriarchal protection and white privilege to all white women. Thus, during the later colonial period, black men and white women who had sex, married, and/or had children were punished and persecuted as American society denied them the right to choose each other as mates. The category 'white' would also mean that people designated 'black' could be held in perpetual slavery." ${ }^{39}$ ( $\mathrm{p}$ 366)

The construct of whiteness has been expanded in similar ways over the centuries so as to continue the legitimation of the capitalist economic order. The assimilation of various ethnic groups (or of a certain few from various ethnic groups) into whiteness, near-whiteness, or the petite bourgeoise, furthers the existence of a disproportionately Black and Indigenous underclass by providing enough social, cultural, or economic capital to those who assimilate to make it seem as if the structure benefits them. Or, perhaps more accurately, assimilation or internalization of ideological hierarchies of worthiness or morality does not necessarily lead to a belief that one benefits from said hierarchies, so much as it leads to the identification of scapegoats who one is socially allowed or encouraged to either do harm or ascribe the harms of social and economic structures.

Omolade presents an example of this in the form of the white housewives of colonial patriarchs, noting how when masters raped enslaved women, wives often took their anger out on the enslaved woman herself. Omolade points out that white women, rather than identifying the common experiences of rape and expropriation of labor, leveraged their racial and social power in ways which were at times even more violent than their white husbands. This is in part related to the heterosexual coloniality which Maria Lugones describes - namely, that white women who perform and internalize as worthwhile bourgeois "light" womanhood also internalize bias and resentment of "dark" womanhood. Violence done unto people placed within the colonially defined "dark" womanhood is excused because of the labeling: European men deem sexual violence natural when they finds themselves aroused, as when they are aroused, they construct that as meaning that someone aroused them, rather than that their frame of interpreting the world depends on patriarchal social constructions which they then write onto space and movement and body and unknown-to-him interactions and performances and societies. In other words, a Eurocentric construction of African people labeled woman, which exists both as legitimizing and out of the expropriation of African women's labor (including but not limited to reproduction), naturalizes/bioessentializes the interpersonal and systemic violences forced upon African women.

"But though it was beyond her concept of enslavement, it was not beyond her master's, for every part of the black woman was used by him. To him she was a fragmented commodity whose feelings and choices were rarely considered: her head and her heart were separated from her back and her hands and divided from her womb and vagina. Her back and muscle were pressed into field labor where she was forced to work with men and work like men. Her hands were demanded to nurse and nurture the white man and his family as domestic servant whether she was technically enslaved or legally free. Her 
vagina, used for his sexual pleasure, was the gateway to the womb, which was his place of capital investment - the capital investment being the sex act, and the resulting child the accumulated surplus, worth money on the slave market." (p. 366)

In Feminist Theory of the State, Catharine MacKinnon examines how the Eurocentric legal constructions of consent legitimize and conceal violent domination:

"Consent as a concept was never designed to apply between two people in civil society. It was given its meaning in western liberal philosophy as the basis for legitimizing the obligation to obey the laws of the state. Even as a fiction, it never envisioned equal parties: it exists to rationalize the exercise of dominant power of subordinates. Applied to sex, he is the government, she is the governed. You are regarded as consenting, for example, whenever you don't leave. You consent because you are there, whether leaving is a realistic possibility of not. Silence in sex, as in governing, is deemed consent not dissent. These assumptions, along with the presumption that the two parties are somehow equals, which is never either articulate or justified, operate powerfully in sex unequal circumstances, contrary to realities. Legal attempts to correct for this social burden of proof - this assumption of yes, women being walking consent - by adding additional words to make "consent" mean anything at all like "positive", "chosen", "affirmative", "autonomous", "informed", "conscious", "freely given"-you have to add all this on to the front of "consent" to make it mean anything - cannot be relied upon to overcome its basic meaning. Fundamentally, it needs to be faced that consent is not an equal concept. It is an intrinsically unequal one that presuppose an actor and an acted upon. The purported form of power of the acted-upon being acts ceding to the actor's actions - in other words, doing what you are told to. It tends to presume the parties are equal, whether they are or not, and relies on an illusory image of women's agency under conditions of inequality, as if we can be free without being equal." 40

This base intention and function of the legal construct of consent underpins the allowance of rape, or more accurately the allowance of some to rape, as well as the legitimation of capitalism. Although, to apply Lugones' identification of the limitations of white feminist conceptions of patriarchy, it's important to understand that while MacKinnon's framework of "he is the government, she is the governed" unquestionably holds a lot of truth, as rape is primarily committed by men, and women are disproportionately raped, it is an incomplete understanding of the effects of the Colonial/Modern Gender System on consent, one which avoids other forms of power inequality which impact the ability to coerce without force, from wealth to race to age, and on. These cannot be simplified into simply a domination of the masculine over the feminine and doing so results in an inaccurate extension of the feminine to those who are raped, rather than a situated exploration of intersecting hierarchies. Does a wealthy white woman engaging in exploitative sex tourism do so because the person she sexualized is feminine? Presuming consent based on colonial perceptions of body does not only include the perception of so-called female bodies as sexual, it also includes the racialized fetishization of 'hypermasculinity', which similarly assumes consent from a perspective of arousal. That said, the Colonial/Modern Gender System does overwhelmingly write on to bodies perceived as either feminine or woman an acceptability to abuse. Sylvia Federici in Caliban and the Witch explores the European history behind this phenomenon, identifying how the witch hunts and state sanctioned abuse of women were orchestrated to undermine labor solidarity and to subjugate women to a lower class than men, defined in part by the rise of the expropriation of feminized labor. ${ }^{41}$ She writes: 
"By the end of the $15^{\text {th }}$ century, a counter-revolution was already under way at every level of social and political life. First, efforts were made by the political authorities to coopt the youngest and most rebellious male workers, by means of a vicious sexual politics that gave them access to free sex, and turned class antagonism into an antagonism against proletarian women. As Jacques Rossiaud has shown in Medieval Prostitution (1988), in France, the municipal authorities practically decriminalized rape, provided the victims were women of the lower class. In $14^{\text {th }}$-century Venice, the rape of an unmarried proletarian woman rarely called for more than a slap on the wrist, even in the frequent case in which it involved a group assault (Ruggiero 1989: 91-109). The same was true in most French cities. Here, the gang-rape of proletarian women became a common practice which the perpetrators would carry out openly and loudly at night, in groups of two to fifteen, breaking into their victims' homes, or dragging their victims through the streets without any attempt to hide or disguise themselves. Those who engaged in these 'sports' were young journeymen or domestic servants, and the penniless sons of well-to-do families, while the women targeted were poor girls, working as maids or washerwomen, of whom it was rumored that they were "kept" by their masters (Rossiaud 1988:22). On average, half of the town male youth, at some point, engaged in these assaults, which Rossiaud describes as a form of class protest - a means for proletarian men-who were forced to postpone marriage for many years because of their economic conditions - to get back 'their own,' and take revenge against the rich. But the results were destructive for all workers, as the state-backed raping of poor women undermined the class solidarity that had been achieved in the anti-feudal struggle. Not surprisingly, the authorities viewed the disturbances caused by such policy (the brawls, the presence of youth gangs roaming the streets at night in search of an adventure and disturbing the public quiet) as a small price to pay in exchange for a lessening of social tensions, obsessed as they were with the fear of urban insurrections, and the belief that if the poor gained the upper hand they would take their wives and hold them in common. (ibid.:13) For proletarian women, so cavalierly sacrificed by masters and servants alike, the price to be paid was inestimable. Once raped, they could not easily regain their place in society. Their reputation being destroyed, they would have to leave town or turn to prostitution (ibid.; Ruggiero 1989:99). But they were not the only ones to suffer. The legalization of rape created a climate of intense misogyny that degraded all women regardless of class. It also desensitized the population to the perpetration of violence against women, preparing the ground for the witch-hunt which began in this same period." (p. 47-49)

As many of the theorists already discussed (including but not limited to Quijano, Robinson, Lugones, and Mbembe) allude to or directly address, one element underpinning the colonial hierarchy is the presumption of unique humanity, wherein man (defined through exclusion) is seen as better than, above, and outside of nature, and nature is seen as to tamed. Mbembe describes this aspect of colonization as such: "That colonies might be ruled over in absolute lawlessness stems from the racial denial of any common bond between the conqueror and the native. In the eyes of the conqueror, savage life is just another form of animal life, a horrifying experience, something alien beyond imagination or comprehension.” (p. 24) Like and intertwined with colonial racialization and gendering, colonial anthropocentrism functions to determine acceptable violences, and acceptable targets of violence. It fetishizes the results of the labors of ecological reproduction into commodities and encourages the extractive rape and conquest of feminized natures. This has catastrophic impacts on ecological systems, and 
the people who depend on those systems to survive. In his piece Marx, Value, and Nature, John Bellamy Foster examines Marx's interpretation of the expropriation of 'natural' labors and concept of metabolic rift. ${ }^{42}$ He writes:

"At the heart of today's metabolic rift, as Marx argued, is the logic of the alienated capitalist system of accumulation, in which all natural boundaries are treated as mere barriers to be surmounted, opening up anthropogenic rifts in the fundamental biogeochemical cycles that constitute the overall Earth System. Ecological crises proper are thus not crises of economic value, but of disruption and destruction of conditions of ecological reproduction and human development at the expense of future generations and living species more generally. Viewed in this way, the primary ecological contradiction resides in the expropriation of nature as a free gift to capital, leading to 'the squandering of the powers of the earth.' This is what Marx meant when he said that the soil was 'robbed' of the conditions of tis reproduction, thereby generating a rift in the metabolism of humanity and the earth." (p.130)

He continues

"The expropriation of the earth has invariably been accompanied by the expropriation of humans as corporeal beings, through innumerable forms of labor bondage and servitude always present at the logical and historical boundaries of the system, helping to make capitalism possible. Such expropriation is always an essential part of the system, determining its parameters. The system of capital, Marx famously remarked 'comes dripping from head to doe, from every pore, with blood and dirt.' The role of slavery, genocide, and every kind of human servitude, including the vile robbing of the earth itself, was crucial both to capitalism's origins and to its continuing antagonistic reproduction. Today the gross exploitation (or superexploitation) through the global labor arbitrage of the mass of the workers in the global South is giving rise to a "planet of slums' and imperialist warfare imposed on the periphery, along with the continued expropriation of women's unpaid labor." (p. 132)

From this, we must recognize that repairing these rifts and ceasing the violence they grow through depends on the cessation of overproduction, both through the end of the expropriation of resources and labors, and through the abolition of institutions and structures which reproduce this unsustainable cycle.

\section{Historical Analysis}

The histories of Southeast Asia prior to and during European colonization are vastly more complex and varied than I can cover in this section. Further, it is certain that this introduction to these people and spaces are negatively influenced by my own ignorance regarding the historical complexities of regional power dynamics and peoples. Given that one tool of imperialist narration is the presentation of a purportedly complete or complete enough linear history which in actuality misses major events, angles, and positionalities, I want to make clear that I am undoubtably missing many of these. In this section, I am not providing a comprehensive analysis, but rather engaging with a selection of resources examining a few aspects of economic structures, governmental legacies, and sociocultural hierarchies in the region.

The area that would by the late 1800s be consolidated under French colonial rule included numerous classes, communities, languages and cultures. The French would split the area they colonized into 5 protectorates, Cambodia, Laos, Cochinchina, Annam, and Tonkin the 
last three of which would later be and had previously been united as Vietnam. $20^{\text {th }}$ century antiimperialist movements of national identities in Laos, Cambodia, and Vietnam, in resistance to colonization, also incorporated reflexive replications of hierarchy and racial purity, which was neither entirely a result of French colonization nor a relic of supposedly ancient feuds. The French coloniality of power constructed and projected a classed racial hierarchy which placed traders and wealthy elites at the top and highland communities at the bottom of the hierarchy. Among the indigenous groups still in what is known as Vietnam are the Bru, the Co Tu, Taoih, the Brâu, the Cor, the Xơ Đăng, the Hrê, Rơ Măm, Cham, and many more. As Quijano said, "All of the dominated peoples had been deprived of their own historic identities." And the French did just this, lumping all these groups into the singular designation of "Montagnard." However, as Karine Delaye notes, which I will explore later, the peoples of Laos, Kampuchea, and Annam all also had derisive terms which lumped highland communities together, each of which translated referred to "slave." Over the course of the anti-imperialist struggles of the $20^{\text {th }}$ century, these groups had widely varying allegiances, aims, and experiences.

Part of this deprivation of historic identities is the gender based. As Lugones describes, colonial perspectives of gender are violently projected onto colonized people, replacing/silencing gender constructions grounded in specific cultural, historical, social, metaphysical contexts. Colonial perspectives of indigenous gender sometimes acknowledged what they perceive to be "transgender" people (quotations not to invalidate people's experiences as trans, but to acknowledge that as the binary of transgender vs. cisgender itself arrives from specific linguistic, sociocultural, and colonial contexts), however colonial perspectives of these people often fetishize, objectify, and demonize those who fall outside the colonial assigned binary.

One source which provides insight to women's resistance to feudal and colonial oppression in Vietnam is Arlene Eisen Bergman's Women of Vietnam. ${ }^{43}$ I should note that while Bergman's book includes invaluable firsthand reports and exhaustive citation, it also unquestionably falls into a discourse community which Judy Tzu-Chun Wu terms "radical orientalism." Wu defines this as the following:

"In forming an internationalist consciousness, American activists both challenged and reinscribed Western perceptions of Asia. The political travelers who journeyed abroad earnestly wanted to learn and expose the 'truth' about the U.S. war in Vietnam. At the same time, their perceptions of Asian people and places were refracted through idealized projections of the decolonizing Third World." (p 4)

Wu argues that this constituted in part a "hierarchical inversion," and that unlike Orientalist constructions of the East,

"The perceptions of Western antiwar travelers, however, were not just projected onto Asia. Asian individuals and political organizations cultivated connections with U.S. activists of diverse backgrounds and interpreted decolonizing Asia for these visitors. In other words, the East and the West worked together to foster a radical orientalist sensibility. These idealized portrayals of decolonizing Asia were not necessarily accurate or complete depictions of these dynamic societies undergoing complex political, military, and social changes." (5-6)

Northern Vietnam, which borders China, has a long history of border disputes and Chinese occupation. Bắc thuộc, or 'belonging to the north' refers to the four periods of Chinese rule over Vietnam. As Bergman outlines, Chinese domination of Vietnam was marked by both the imposition of patriarchal Confucianism and the rise of a Vietnamese national identity driven by women's opposition to domination. In $40 \mathrm{AD}$, the Trưng sisters, Trưng Trắc (later renamed 
Trưng Vương, or She-king Trưng) and Trưng Nhị, along with 36 women generals, led an army of 80,000 against the Chinese occupation, liberating 65 fortresses. Although the Chinese defeated the rebellion in $43 \mathrm{AD}$, the sisters became heroes.

"By the twelfth century, the Trưngs had become goddesses with temples built in their honor. Confucian scholars tried to superimpose a patriarchal interpretation onto their legend by giving a greater role to the husbands of the Trung sisters. But peasants and rebellious Vietnamese dynasties restored the Vietnamese version of the legend." (p. 31) While official records "gave the impression that all women were content to live their lives guided by the rules of chastity and the "Three Obediences"” (P.32), Vietnamese women reproduced a legacy of opposition to and mockery of patriarchy through folksongs and poetry, including the incredible:

"We honorable sisters are like a mass of boulders in Heaven.

How could you youngsters as small as mice think of disturbing us?

Cursed be you bunch of mice,

When this rock falls down, your bones will be crushed." (P.33)

The Tây Sơn rebellions of the late $18^{\text {th }}$ century are frequently presented, including by Bergman, as a series of uprisings by peasants, people from the different highland communities, and prisoners of war against the northern Trịnh lords and the central/southern Nguyễn lords, which united the country. This narrative was politically useful as a historical precursor to the anti-imperialist revolutions of the $20^{\text {th }}$ century. However, George Dutton has argued that the brothers, and those involved in the uprisings, had conflicting political and economic goals. Although many of those involved were peasants, and the mobilization of armies depended upon preceding political oppression, the brothers themselves were well off, and upon unification saw themselves as rulers. Further, he argues that for most under Tây Sơn rule, life did not drastically improve, rather the worsening of conditions for some under Nguyễn rule contributed to the development of an opposition narrative of the Tây Sơn uprisings, which became politically useful during the $20^{\text {th }}$ century anti-imperialist struggles, in which constructing a national identity was politically important.

"Although many peasants were unhappy with the difficulties of life under Tây Sơn rule, these same peasants were equally displeased with Nguyễn authority, and at least some compared Tây Sơn governance favorably to that of the Nguyễn.” (p 232)

Dutton's historiography indicates a pattern similar to that Cedric Robinson describes and discusses in his chapter of Black Marxism on Racial Capitalism, namely, that ruling capitalist classes do not evolve from one another in a linear history but instead are "an opportunistic strata, willingly adaptive to the new conditions and possibilities offered by the times." 44 (p.19) This is a potentially important point, given the later use of the Tây Sơn rebellions as a blueprint of sorts for revolution.

The fall of the Tây Sơn dynasty is also important due to the involvement of the French. During the Tây Sơn rebellions, the Nguyễn family was slain, with the exception of Nguyễn Phúc Ánh, later known as Gia Long. Gia Long would soon seek help from Pierre Joseph Georges Pigneau, a French Catholic priest who sought the government's assistance in restoring the Nguyễn dynasty. The French government, on the brink of revolution itself, signed on to a free trade agreement which included ships and soldiers but ultimately reneged, and Pigneau sought support from French merchants instead. Pigneau's support led to Gia Long's relative permittance of Catholic missionary activity during his reign. His successor Minh Mạng shifted this course, attempting to limit Catholic influence and spread. Minh Mạng’s son and successor Thiệu Trị 
continued these policies. The French would use these contexts as an excuse to begin militarized colonization efforts. One of these inciting incidents was when a Dominique Lefèbvre, a missionary who, in opposition to Vietnamese law which did not permit the entrance of Catholic missionaries, snuck into Vietnam to proselytize twice ${ }^{45}$. Between 1858 and 1862, using religious persecution of Catholics as imperially acceptable grounds, the French Empire and Kingdom of Spain waged war against the Nguyễn Dynasty to establish and later expand French colonies in what they would term Indochina.

\section{Hierarchy, Labor, and Violence under French colonization}

The French were a colonizing empire fighting dynasties for access to and control over the labors and wealth of the peasantry and land. The French mission civilisatrice aimed to simultaneously portray the pre-colonial governments as barbaric and backwards, while supplanting the existing asymmetrical feudal labor structures with white supremacist colonial labor hierarchies and relations. Colonizers both imposed Eurocentric, extended existing, and remade through commodification racial, national, class, and sexual hierarchies.

One example of this is the racialization of modernity and the practice of slavery. For French colonizers, the existence of slavery prior to colonization was narratively and officially a way of solidifying what Quijano termed "a continuous historical chain from 'primitive' to 'civilized'", under the claim that 'French soil frees the slave who touches it'. ${ }^{46}$ (Delaye 129) In actuality this was a falsification, a myth of civilizing which obscured the dependence of the French empire (and capitalism more broadly) on enslavement, and the specific context of the colonization of Southeastern Asia as embedded in French 'emerging' slave markets.

Karine Delaye's reading of primarily Eurocentric accounts of the history of slavery (which she defines by status as property, rather than by working conditions or coercion) in Indochina indicates that there were a variety of existing hierarchies, social/economic positionalities, and legal structures which might be used as grounds for enslavement, such as certain forms criminality, prisoners of war, impoverishment, perceived witchcraft, disability, and ethnicity. However, as Quijano described in relation to America:

"Slavery was deliberately established and organized as a commodity to produce commodities of the world market, that is to say, to serve the purposes and necessities of capitalism, and it was structurally articulated with one specific 'race'." (p. 218)

Bergman describes the state of slavery in French Indochina as the following:

"French policies in Viet Nam assumed that the Vietnamese people were not worthy of the same rights as Frenchmen. In European eyes, this 'Oriental race' was expendable. The French kidnapped eighty thousand people to build a railroad to ship their goods to port. Twenty-five thousand of them died. Conditions in the coal mines run by the French were so bad that the French could not get the Vietnamese to work voluntarily in the mines. They had to destroy dikes and flood entire villages in mine areas to make it impossible for the people to earn a living from farming, leaving peasants with no choice but to work in the mines. Still, they had trouble recruiting workers. Fifty thousand men and women died at work in the mines. Desrousseaux, Inspector of Mines, wrote a secret report addressed to the Governor General in 1940:

'The peasants will consent to go and work outside their villages only when they are dying of starvation. We must therefore arrive at the conclusion that in order to extricate 
ourselves from the difficulty of recruiting labor, we must see to it that the countryside is plunged into poverty.'

The French policy to 'plunge the countryside into poverty' was successfully

implemented. The average peasant got poorer and poorer as larger and larger plots of and became concentrated in fewer and fewer hands. Before the French arrived, the maximum amount of land a court official could legally own was barely ten acres. By 1930, the French had two-thirds of the cultivated land in their control. Most of the peasants had no land at all and were caught in a vicious cycle of debt slavery. The few peasants who still owned land had to mortgage it to pay taxes at interest rates that went as high as 3650 percent. By making the peasants desperate to survive, the French strengthened the hand of the feudal notables and used them to collect taxes and force men into the French army and labor chain gangs." (p. 41)

The percent of cultivated land Bergman cites is likely an exaggeration, with Trương Bửu Lâm citing that by 1932 European control of land totaled about $20 \%$ of all cultivated land, however as he points out this was "an enormous portion, considering the small number of French citizens living in Vietnam" (p. 41) ${ }^{47}$ Regardless of the specific total, we can see the conscious interdependence of ecocide and genocide in capital accumulation, where French policy was to intentionally sever modes of reproduction to create dependence through ecological destruction, so that they could expropriate the wealth of the land through the expropriation of Vietnamese labor and death.

In his book Colonialism Experienced, Trương Bửu Lâm writes a comprehensive and wide-ranging account both of the ways in which coloniality affected the lives of the colonizer peoples, from military conscription, to linguistic reverberations of hierarchy, to the daily abuses by French invaders, and of the ways in which colonialism was described by those experiencing it. He identifies colonization as a form of slavery, quoting from the masthead of Nguyễn An Ninh's publication La Cloche Fêlée, "People pay to be served; colonized peoples pay to serve, they pay to be enslaved" (p. 70). He further quotes on the effects of colonization:

"Vietnam was an empire, an independent state; France reduced it to slavery by making it a colony. The Vietnamese were a free people with pure customs; France has turned them into a horde of traitors and slaves. Vietnam had no secret police; today, the French colonial administration snoops constantly on the people through a multitude of squealers who thrive within and without the country. The Vietnamese had the liberty to educate themselves; at present, the French colonial government detains the monopoly of education and takes advantage of that power to hinder the evolution of the Vietnamese people through a very smart system of obscurantism. Vietnam could have elevated itself to the level of other newly modernized countries of the region but instead France has reduced it to the status of the most ignorant and the most backward land in all of Asia. There is no freedom of the press. There are, on the contrary, the state monopolies of alcohol and opium. The Vietnamese people are oppressed by the heavy weight of taxation and the contributions while French civil servants gobble up each year 80 percent of the budget's revenues. Vietnam had no standing army, so there existed no military conscription; today, French imperialism compels the Vietnamese, who no longer have anything to protect to serve in the army for 4 years while French citizens are conscripted only for 18 months." (p. 71)

Following Federici, the "accumulation of differences" present in the direct, structural, interpersonal, and hegemonic violences of colonization consists not only of the establishment of 
a Eurocentric racial hierarchy, but of intersecting hierarchies of gender, humanity, health/ability, sexuality, class, and on. These hierarchies were established and upheld through violence, trauma, and destruction.

In "Syphilis, Opiomania, and Pederasaty", Frank Proschan describes French colonial discourses/constructions/projections of racialized sexuality and racially sexualized health. ${ }^{48}$ The title refers to a quote from Paul Michaut, a French colonial 'scientist' who, out of concern for "the moral enfeeblement of our soldiers" focused his studies on the spread of syphilis in relation to opium and the rape of young boys. Michaut, blamed the rape of young boys on the "Annamite woman...rendered hideous by certain incorrigible habits (lacquering of teeth in black which transforms the mouth into a horrible cavern that seems toothless, the general habit of chewing betel which stains the tongue and lips with a red juice that the woman spits out at every instant.)" (p. 612) This colonizer's projection/perception/construction of, to recall Lugones, a "dark side" of gender existed within a broader colonial gendered demonization and degradation, one which blamed those who were abused by colonizers, projected the fetishization colonizers internally constructed onto the bodies of those they raped. This is demonstrated by the French linguistic imposition/translation of the woman category. Proschan writes: "In Vietnamese, con gai simply means 'young woman, girl, female child,' but its semantics in the French discourse shifted over time from 'woman' to 'wife' to 'mistress' to 'whore,' ultimately accomplishing linguistically the degradation of all womanhood to whoredom." (p. 614)

Michaut also claimed that syphilis would be worse in effect for those engaged in same sex sexual relations, giving a 'rational' explanation for heterosexualism. Proschan explores how 'scientific' racialized discourses attempted to identify an ethnic source of same sex child rape, often dismissing the centrality of European colonizers to the practice. Health discourses were also primarily concerned with racial purity and domination, indicated by the lack of care for the impacts on anyone except colonizers. These discourses served to solidify racial, sexual, and gender hierarchies both within the colony, and in relation to the imperial core. In France, they likely also served to identify to predators that the colony was a place in which an invader could rape or engage in sexually deviant acts with whomever they wanted without punishment. The fetishization and dehumanization of the people of Vietnam bolstered colonizers' feelings of entitlement to both sexual and nonsexual labor, as well as to the bodies of the people they encountered.

In "Crises of whiteness and empire in colonial Indochina" Christina Firpo traces the history of French colonial kidnapping of "abandoned" Eurasian children, abandonment referring to the absence of the French father. ${ }^{49}$ In other words, the colonial government targeted single Vietnamese mothers, considering them harmful influences on their own children, whose bodies the government saw as a battleground for racial domination. Firpo identifies that in the eyes of insecure French colonists, these children, dependent upon "[whitening]" and gender, had either "the potential to reveal the vulnerabilities of whiteness" or the potential to "bolster declining white population numbers". (P. 589) Eurasian protection societies, using a patriarchal 1889 French law which "declared that the state could claim paternal rights over children who had been physically or morally abandoned by one or both of their parents" (my emphases) In this, the government essentially allowed colonists to have sex with or rape and subsequently abandon Vietnamese girls and women, and then after the girls and women had done the reproductive work of creating a child, the government claimed to have rights over their child, and actively sought out and kidnapped these children from their mothers. The treatment of children was also consciously gendering: 
"Because abandoned Eurasian males did not meet French standards of masculinity, the colonial government and Eurasian protection societies sought to make "men" of them, Frenchness being equated with masculinity.

As for abandoned Eurasian girls, there was no discussion of making "ladies" of them; the aim was simply to prevent them from becoming prostitutes and usher them into marriage with whites or other francified Eurasians. Meanwhile, the Vietnamese mothers of abandoned Eurasians were perceived by the French colonists as an obstacle to the francification process. (The children's French fathers, being absent, were rarely discussed.)" (p. 588)

These 'societies' parallel the functions of Child Protective Services, which both historically and currently functions as a white institution disproportionately targeting, criminalizing, and separating Black families, with particular focus on single mothers. Dorothy Roberts has written on this institutional violence extensively ${ }^{50}$. Historically, CPS also targeted Indigenous families, although there are more protections in place to prevent this since the 1978 Indian Child Welfare Act. ${ }^{51}$ That said, ICE concentration camps continue to be a place of forcible, racialized family separation, as do both adult and child prisons. ${ }^{52}$

Similar in hierarchical knowledge production were Catholic schools. Catholic schools in Vietnam, as in California, were frequently violent spaces of assimilation and enslavement. In his memoir The Red Earth, revolutionary Trần Tử Bình writes of his experiences as a youth in a Catholic school, and his path towards and through struggle as a worker on a rubber plantation. In describing the hierarchy at the mission, he writes "In the Hoang Nguyen seminary we were stifled, ill-treated, and scorned. At that time the head of the seminary was Father Quy, a Canadian priest. Father Quy did not practice what he preached. He enjoyed himself like a prince. His meals meant the table filled with an abundance of meat and fish, more than he could possibly eat. Night after night he could not get to sleep without a woman... Our meals consisted of a dish of tough spinach and rice stretched with two parts corn to each part stale rice. Meat and fish were scarce as gold." (p. 7-8) Later, he describes a comrade explaining the commonality between the missions and the plantations as such: "the nature of rent paid to the mission was no different from the nature of rent paid to a landlord." (p. 49). As he grew older, he encountered a few people challenging colonial rule, one of whom encouraged him to proletarianize by going to work on the rubber plantations and seeing for himself the extent of the violence. These plantations were exceptionally deadly sites of extraction. As David Marr notes in the introduction, the official French records, which undoubtably concealed the extent of violence, indicate $17 \%$ of the workers died in 1927 alone. Trần Tử Bình described how the initial conditions on the ship to Saigon were very harsh, but that the workers went on a hunger strike and were able to protest their way to better food. However, this was short lived. Upon arrival they were beaten viciously, placed into what amounted to a concentration camp, before being separated to be sent to various plantations, undermining both the connections and power they had built as a collective. Once at the plantation, overseers beat them further and killed one person, establishing the stakes of non-compliance. He writes:

"The overseers drove us to fell trees, clear out underbrush, then dig holes to plant the rubber trees without rest. Finally at six in the evening we returned to the village, everyone of us bone tired. But when we reached the village, we had to busy ourselves carrying bamboo tubes down to the stream for water, and finding a few sticks of dry firewood to kindle a fire to cook our dinner. We would then grill our dried fish on the fire until we could smell it charring, then toss everything together and eat. When we were 
especially dried out, we might go hunt for mushrooms and leaves like poor scholars, cooking some tasteless soup of mangosteen leaves or whatever we happened to find to ease the pain.

At the end of the day a person really had no enthusiasm left, but wanted nothing more than to slip into the barracks and fall asleep so that the next day, when the overseer's siren sounded again, he could get up, eat, and begin another day of backbreaking work. One's strength today was never what it had been the day before. Every day one was worn down a bit more, cheeks sunken, teeth gone crooked, eyes hollow with dark circles around them, clothes hanging from collarbones. Everyone appeared almost dead, and in fact in the end about all did die." (p.28)

The felling of workers and trees were interdependent processes. Widescale expropriation of socalled 'natural' resources could only co-occur through the expropriation of death and trauma. Torture, rape, and disease all maintained the racialized and gendered labor hierarchies on the plantation. Despite and because of the intense and constant violence, they resisted, in secret. A few tactics they utilized were slowdowns where they went by the pace of the weakest worker, killing the saplings, and secretly developing a Red Guard unit who would intervene to stop the rape of women, as well as to defend the movement when needed. Through attempts to go through official colonial bureaucratic complaint processes they learned the significant limitations of legal resistance. After the murder of a foreman who the French believed didn't beat the workers enough, the complaint process resulted in a measly 5 piaster payment to the foreman's wife. The attempts to alert bureaucratic inspectors also fell flat, after they were paid off by the manager. This provides insight to the limitations of today's world as well-although the commonality and extensiveness of available information provides a sense of understanding the world, this is limited dangerously by the filters through which information is able to pass through. Workers unquestionably attempt to make their struggles known today using media, at times very successfully, and still much of the violence and resistance to capitalist hegemony remains unknown, un(der)reported on, or intentionally suppressed.

Another element of his memoir worth noting is how both the workers and the French engaged with the groups of people who lived in the Highlands. He writes:

"The imperialists also schemed to sow and deepen divisions among the various nationalities. The forest region of Phu-rieng was populated only by compatriots of the mountain minorities. Because of restraints imposed by the feudalists and the imperialists, they were at a very backward, impoverished level. The men rolled themselves primitive G-strings; the women added a piece of cloth to cover their bodies. Every day they slung baskets on their backs and went out in the forest to search for fruits and firewood. On rainy days they would hoe up a few plots of land to grow rice on terraced fields. In normal times they would take spears and crossbows into the forest to hunt wild dogs and foxes. When the rice was harvested, however, they would do an about-face and lie about drinking wine and singing and wasting time in their houses. And so they needed salt and cloth.

Taking advantage of the backwardness and those needs, the imperialists threatened and enticed the mountain minorities to follow them. One of the first things they did was to play on people's superstitious minds by making fire. It was not particularly difficult. All they had to do was pour permanganate and glycerine on cotton, and fire burst out. The mountain people thought the imperialists had miraculous powers, so some feared and admired them. They enticed the people, saying: 'Whoever catches a runaway worker and 
turns him in to 'monsieur' will get a reward of salt and money from 'monsieur.' If you turn the worker loose, 'monsieur' will set fire to your house and your fields. 'Monsieur has miraculous powers, so no one can hide anything from 'monsieur'.... Later we were able to convince the mountain people. When they understood what was going on, they helped workers escape the hands of the enemy. We took a vow of brotherhood with them, eating food and drinking wine to seal our pledge to regard each other as flesh and blood relatives. Having picked up some knowledge of medicine at the Phu-rieng infirmary, I would treat those compatriots whenever I found any of them ill. Many people were cured, so they gained confidence in me and were very grateful... The rows of rubber saplings encroached little by little on the ancient forests, invading even the corn and rice fields of the mountain people, driving them deeper and deeper into the forests. So they understood all the more what we were saying. They lamented to me: 'We are from the same family and love each other. But 'monsieur' is not a brother form our family. 'Monsieur' is so cruel. 'Monsieur' is forever taking the land of the 'savages.' How, then, are the 'savages' to live?" (p. 31-32)

The French violences, later to be replaced by American violences, of the minority groups living in the highlands are clearly evident. The expropriative colonial land-use not only involved the murder and death of tens of thousands of workers, and the destruction of ecosystems, but the violent encroachment on Indigenous lands. Both the French and the Americans would also enslave people in the mountain communities. I also believe that Trần Tử Bình description of solidarity with these groups and the destruction of the lands they lived on is filtered through an internalized superiority. As he identifies at the beginning, this was largely the work of colonization which he lived under. The goal of the imperialists was in part deepening (implied to be existing) division. He isn't at fault for internalizing, through repeated violence, colonial constructions of a 'modern'/'primitive' time split. More, it's worth noting, there may be error or distortion in translation, and his is only one narrative. That said he describes in extended detail the ways in which he believed these people to be "backwards". Another implication in the descriptions he gives here, and throughout the book, which make a lot of sense given the context of a life-or-death situation, but which highlights a schism that becomes more relevant as the antiimperialist movement expands, is that whether he views them as 'noble' or 'brutal' is dependent upon which side they support. Each of these stereotypes linguistically erases agency and dehumanizes the people they are applied to. Overall, this passage introduces one of the dilemmas of unpacking the role of colonization on these groups: that the indigenous people in question are represented, rather than speaking for themselves. I would like to remind the reader that as I am writing this, I am doing this as well, and my perspectives should be criticized accordingly.

\section{From French Colonialism to American Neocolonialism}

After Germany defeated France during WWII, Japan invaded Indochina. Nick Turse summarizes:

"The League for the Independence of Vietnam...launched a guerrilla war against the Japanese forces and the French administrators running the country. Under the leadership of the charismatic Ho Chi Minh, the Vietnamese guerrillas aided the American war effort. In return they received arms, training, and support from the U.S. Office of Strategic Services, a forerunner of the Central Intelligence Agency. 
In 1945, with the Japanese defeated, Ho proclaimed Vietnam's independence, using the words of the U.S. Declaration of Independence as his template. "All men are created equal,' he told a crowd of half a million Vietnamese in Hanoi... however ... The Americans saw France as a strong ally against any Soviet designs on Western Europe and had little interest in sanctioning a communist-led independence movement in a former French colony. Instead, U.S. ships helped transport French troops to Vietnam, and the administration of Harry Truman threw its support behind a French reconquest of Indochina.

Soon, the United States was dispatching equipment and even military advisors to Vietnam. By 1953, it was shouldering nearly 80 percent of the bill for an ever more bitter war against the Viet Minh. The conflict progressed from guerrilla warfare to a conventional military campaign, and in 1954 a Gallic garrison at the well-fortified base of Dien Bien Phu was pounded into surrender by the Viet Minh forces under General Vo Nguyen Giap." 53 (p. 7)

During the 1954 Geneva Accords, the U.S. and South Vietnam refused to sign. The negotiation had been for an election, but the election was expected to be won by Ho Chi Minh. A few months before that, Chairman of the Joint Chiefs of Staff, Admiral Arthur Radford sent a memo suggesting the use of atomic bombs if it "[appeared] militarily advantageous." 54 (p.124) From the very beginning, the war was expected to be genocidal. By the non-signing of the accords, the U.S. had established a paramilitary team in Vietnam and begun to threaten the population, sabotage Northern public transportation, and train local forces. Contemporaneous research showed the Viet Minh were intending to abide by the elections and ensure the democratic process ran smoothly. As the date approached in 1956, Ngô Đình Diệm, backed by CIA Director Allen Dulles and Eisenhower, began blaming the eventual South Vietnamese noncompliance on a supposed lack of "conditions for a free choice in the North" ${ }^{55}$ (pg. 28). As Jessica Chapman explores in Cauldron of Resistance, the choice to "confer legitimacy onto" Diệm was itself based in colonial perspectives of political complexities of South Vietnam ${ }^{56}$ The Americans falsely perceived the Cao Dai, Hoa Hao, and Binh Xuyen, who collectively controlled much of South Vietnam in practice (as opposed to Diệm's limited control outside the palace) as "parochial, antimodern, and incapable as well as morally unworthy of participating in a nationalist government." (p.5)

Had the U.S. not backed the Diệm regime, there still would have been a civil war. But what would the extent of violence have been, in comparison? Would millions of people be dead, millions of people disabled, millions of people displaced? Would millions of acres of forest, agricultural lands, and communities be destroyed? But the U.S. was faced with an option, mind their business, or attempt to replace the French as a neocolonial force behind South Vietnam. True to pattern, the former wasn't really an option. Like the French before them, the Americans were fighting for access to a labor force, first in the form of military force and conscription, and later in the form of labor and resource extraction. Had the South won, or had Vietnam remained divided, the Americans would have control over a government they could use to ensure ongoing military, economic, sexual, and ecological domination of the populace, like they had established in South Korea.

Recalling again Quijano's quote “All of the dominated peoples had been deprived of their own historic identities" is useful in understanding how those in charge of the war saw the peoples they pledged to put to death, and the places they chose to ravage. As William Blum writes: 
"To the men who walked the corridors of power in Washington, to the military men in the field, Indochina - nay, Southeast Asia — was a single, large battlefield. Troops of South Vietnam were used in Laos, and Cambodia. Troops of Thailand were used in Laos, Cambodia and South Vietnam. Thailand and the Philippines were used as bases from which to bomb the three countries of Indochina. Military officers in South Vietnam, Thailand, and Taiwan were trained at American schools in the Philippines. CIAsupported forced carried out incursions and invasions into China from Laos, Burma, and Taiwan. When there was a (much-publicized) pause in the bombing of North Vietnam, more American planes were thus available to increase the bombing of Laos. And so it went." (p. 127-128)

Nkrumah also argues that "if the social conditions occasioned by neo-colonialism cause a revolt the local neo-colonialist government can be sacrificed and another equally subservient one substituted in its place." One example of this can be seen in the U.S. support of the coup and assassination of Ngô Đình Diệm in 1963 following mass protests in response to police brutality and murder of Buddhists protesting religious repression.

Over the course of the war, an estimated 3.8 million people died violent war related deaths. This was not the natural result of warfare, but an extension of the commodification of death under white supremacist imperialism. Where the French desired and created a "sovereign right to kill", the American invaders extended this through their own particular exterminationism, built off of centuries of genocidal settler colonization, hot off the atomic bomb. The "technowar" system of the military itself was dehumanizing in ways aimed at producing an 'effective' genocide, and this was bolstered by a top-down genocidal racism. The U.S. military aim of killing as many people as possible depended upon the indoctrination of soldiers into a brutal white supremacist ideology. Nick Turse, in Kill Anything That Moves writes:

"The piling up of Vietnamese bodies to be counted - and in a sense discounted - was facilitated by the contempt that Americans generally had for the country and its people. To President Johnson, Vietnam was 'a piddling piss-ant little country.' To McNamara, a 'backward nation.' President Nixon's national security adviser Henry Kissinger called North Vietnam a 'little fourth-rate power,' later downgrading it to 'fifth-rate' status. Such feelings permeated the chain of command and they found even more colorful voice among those in the field, who regarded Vietnam as 'the outhouse of Asia,' 'the garbage dump of civilization,' 'the asshole of the world.' A popular joke among GIs went: 'What you do is, you load all the friendlies [South Vietnamese] onto ships and take them out to the South China Sea. Then you bomb the country flat. Then you sink the ships.' Others swore the best solution to the conflict was to pave the country over 'like a parking lot'. An even simpler proposal was commonly offered 'Kill 'em all and let God sort 'em out.'

He goes on to explain how the application of a military-based racist slur normalized mass slaughter:

This held that all Vietnamese-northern and southern, adults and children, armed enemy and innocent civilian - were little more than animals, who could be killed or abused at will. [It] enabled soldiers to abuse children for amusement; it allowed officers sitting in judgment at courts martial to let off murderers with little or no punishment; and it paved the way for commanders to willfully ignore rampant abuses by their troops while racking up 'kills' to win favor at the Pentagon." (p.49) 
From the perspective of loyal followers of the white supremacist cult of the military, there wasn't really a distinction between genocide and ecocide, because they did not see the people they murdered as people, or perhaps more accurately, in the actions of murder and rape and torture, they claimed to not see these as people because by casting the people they kill as inhuman they excuse the violence they do, they preserve a sliver of their own self construction. They construct racial hierarchy through genocide, and in so doing blame the people they murder. The fluid construction of race means that the histories of and distinct struggles and resistances of Philippines, Haiti, Nicaragua, Korea, and Vietnam are erased in the application of a slur which is applied to any group which higher ups have pointed the soldiers to and said 'kill'.

Alongside this dehumanization was the cooptation of indigenous struggle, which would in the long run, like the French, "sow and deepen divisions," putting a target on the back of those they had taken advantage of. In Laos, and in Vietnam, the U.S. replaced a French piaster trafficking overvaluation racket with the Commercial Import Program, which functioned similarly, allowing for black market money shuffles that turned one dollar into two (not an actual example, but that gets to the gist of it). ${ }^{57}$ It was, unsurprisingly, a source of corruption, one which the CIA headed, as in, "the CIA acquired nearly all of its local currency-millions of dollars worth - through black market transactions.” (Marshall). Workers didn't like the corruption, also unsurprisingly, and in the 1958 elections, the Pathet Lao and other leftists won a majority of contested seats for the National Assembly. So, the U.S. forced Prime Minister Souvanna Phouma to 'resign', and the non-left majority in the Assembly voted to dissolve the body. In his last days in office, Eisenhower approved Operation Momentum, the CIA plan to build an army in Laos, beginning with the recruitment of Hmong people, although later people from other groups were added. Blum describes the secret war, saying:

"Laos was an American plantation, a CIA playground. During the 1960s, the Agency roamed over much of the land at will, building an airstrip, a hangar, or a base here, a warehouse, barracks, or a radar site there; relocating thousands of people, entire villages, whole tribes, to suit strategic military needs; recruiting warriors 'through money and/or the threat or use of force and/or promises of independent kingdoms which it had no intention of fulfilling, and then keeping them fighting long beyond the point when they wished to stop;"' (p.142)

He also quotes from a 1971 Guardian article:

"ample evidence exists to confirm charges that the Meo [Hmong] villages that do try to find their own way out of the war-even if it is simply by staying neutral and refusing to send their 13-year-olds to fight in the CIA army-are immediately denied American rice and transport, and ultimately bombed by the US air force." (p. 144)

This policy of military enslavement, starvation, and extermination was not limited to the Hmong, nor were all of the Hmong people who went to fight with the Americans simply victims of circumstance. The Americans and French alike used the disenfranchisement the Hmong faced in Laos as recruitment. For some of those recruited siding with colonizers meant access to power and wealth. Like with the Viet Minh, others saw the U.S. as a potential ally in a fight for representation and self-governance, or as a way to avoid Lao (or Kinh in the case of Vietnam) majority rule. Over the course of the war, about 50,000 Hmong civilians were killed, including nearly $1 / 4$ of all Hmong men and boys. ${ }^{58}$ The Pathet Lao victory also came with the persecution of Hmong, and led to a significant portion of the population fleeing Laos, most refugees eventually arriving in the U.S. As of 2015, there are about 300,000 Hmong living in the U.S., with $28.3 \%$ 
living in poverty, nearly twice the percent of all Americans, and nearly three times the rate of white Americans. ${ }^{59}$

Karen Coates relays how the head of a UXO clearance group describes the ongoing threat of UXO:

“"A lot of people die in Sepon,' he says. He knows of one family that lost three kids in one day; they were scrap hunting. Ironically, as we talk, three booms sound in the background - they could be controlled detonations, or fisherman using explosives. Or they could be accidents. This is a heavily contaminated area. When he started work here in 2000, he says, his taem found eighty-six 'big bombs' in one week's survey. He tells us about a dangerous bomb in the heart of Sepon. 'If you go to the hospital, there is a house there in front. If you ask them about a bomb, they will show you.' He says he doesn't have the right equipment to destroy that bomb, which has two bad fuses. 'I don't want to touch this bomb,' he says. 'I don't want to die.'...

There, about eight inches down in a hole, is a bomb bigger than a grown man's leg. It sits in a triangle of land adjoining three houses. Fifty yards away is the interdistrict hospital.

The bomb would destroy it if it blew." (p. 280-281) ${ }^{60}$

In Laos, around 80 million bombs remain unexploded. Clearance work has quartered the number of people killed each year (now around 50 people every year), and 50,000 people have died since the end of the war. ${ }^{61}$

\section{Chemical Warfare, Disability, and the Green Revolution}

Between 1962 and 1971, the U.S. sprayed 19 million gallons of herbicide over North and South Vietnam, Laos, and Cambodia during Operation Ranch Hand, and dropped 7.5 million tons of bombs, decimating land and targeting women and children, intentionally and violently intervening in the reproduction of the population ${ }^{6263}$.

Bergman writes:

"During the heavy carpet bombing in both north and south, U.S. aircraft timed their raids to take the greatest toll of lives. They attacked factories during shift change, population centers during meal times or while people slept, churches during mass, schools during class hours, and marketplaces while they were crowded with shoppers. Most of the victims were women and children. The men were away at the front.

Women living in 'free fire zones' had to endure incessant attack. They reported: In some areas, helicopter gunships hovered overhead ready to strafe any moving individual. In others helicopters circled all night, their powerful searchlights illuminating the terrain ('So bright that you can see a needle on the ground') uninterruptedly strafing the pathways so that movement was impossible. B-52's joined the assault... 'Each morning when we wake up, we don't know whether we are living until we open our eyes.' In the South, 'Zippo Brigades' left surviving women and their families homeless. L/Cpl Thomas Heidtman, $1^{\text {st }}$ Marine Division testified:

He [the company commander] said, 'We're going to have a Zippo inspection right now.' and I would say approximately two thirds of the entire company had Zippo lighters. We held them up, lit them, demonstrated that they were filled, would burn. Then put them away. He smiled and let it at that. We went out. I would say at least fifty percent of the villages we passed through would be burned to the ground. There was no difference 
between the ones we burned and the ones we didn't burn. It was just that where we had time, we burned them.

What they didn't burn, they flooded. The Pentagon has admitted that after deliberately bombing dikes, Phantom jets would seed clouds with silver and lead iodide. According to an article in the Los Angeles times, May 19, 1974, U.S. military experts claimed they intended to make the 'Ho Chi Minh Trail' impassable. But the fact is that thousands of people lost their homes in floods." (p.92-93)

Again, we see that genocide, ecocide, and displacement were all part of a connected aim of subjugation. The mass disabling of the population was very clearly embedded in a white supremacist eugenicist approach, one which centered on disabling and killing children, labeling their bodies as the site of a future population whose potential power the US wanted to dismantle. At least a quarter of a million children were killed in the war, and countless more were disabled. ${ }^{64}$ This was exacerbated by the situation of healthcare. Remembering the scale of violences which would require healthcare assistance: South Vietnam only had 100 hospitals, with about 25,000 beds. Hospitals were woefully undersupplied, overcrowded, and were regularly bombed by the U.S. ${ }^{65}$ As for the long-term effects of the herbicides, Deborah Dainton writes for The Vietnamese Association for Victims of Agent Orange, ${ }^{66}$

"It is thought that the chemical enters the genes, and is passed on from one generation to the next. It is known to have entered the food system via the land and rivers. Nobody knows exactly how many generations will be affected.

At present three million people are affected and 4.8 million people have been exposed. They are the poorest people in the country. $70 \%$ of the families are classified as living below the poverty line and $22 \%$ of the families have three or more victims. Many are very seriously disabled; $90 \%$ are jobless. The burden of care for these victims falls on their parents or relatives, many of whom are now in their old age. The problem is great, and will be made more so when the parents and carers of these victims eventually die." In the long term, this has meant the creation of dependency on assimilation into wage labor structures for those who provide for people disabled by dioxin, as well as the mass expropriation of care labor. This also places disabled people at higher risk of abuse without escape due to the exacerbation of interpersonal dependency for survival. According to Palmer et. al, at least $8 \%$ of the population of Vietnam has a disability, but this is using the Washington Group on Disability Statistics short set of questions, which leaves out a huge number of disability measures, including those related to chronic pain, as well as 'mental' health (quotes because of the inaccuracy of separating body from mind) ${ }^{67}$ The exclusion of chronic pain is of particular note given that women both more frequently experience chronic pain, and are significantly less likely to receive adequate care for chronic pain. That said, the undercounted estimation, applied to the 95.54 million population, would account for 7.64 million disabled people. Unsurprisingly, disability frequency and severity are significantly higher in areas which sustained higher bombing and spraying.

Vietnam is currently working towards universal health coverage and has a private-public health care system in place which prioritizes preventative care, which is free. The vast majority of the population, $87 \%$ as of 2018 , is covered by health insurance, and many vulnerable groups are subsidized. Vietnam has reduced maternal mortality from 68 per 100,000 live births in 2000 to 43 in 2017, and reduced childhood stunting under the age of 5 to a third of the level it was at in 1994. However, Vietnam's healthcare is separated based on formal or informal labor, and unpaid care workers, who are more likely to be women, have to enroll in a voluntary healthcare 
plan with less comprehensive coverage than formal sector coverage. ${ }^{68}$ The hierarchy of access to healthcare based on waged labor over non-waged labor is problematic, as it disproportionately impacts those who cannot hold a job and encourages the assimilation into the wage labor structure. It also may reflect neocolonial narratives of modernization as market oriented, and access to independence as granted through production. Further, out of pocket expenses are high in Vietnam, accounting for $45 \%$ of Current Health Expenditure as of 2017, a rise from 37\% between 2005 and $2011 .{ }^{69}$ Palmer writes

"There is a decrease in the incidence of poverty and poverty net of health expenditures for ethnic minority persons; the impact on both indicators is positive for the disabled and the retired. The impoverishing effect of out-of-pocket payment for healthcare is greatest for the disabled. Our findings, consistent with those of Wagstaff and van-Doorslaer (2003), suggest that it is non-hospital costs (medication and travel) that are pushing the insured into poverty. The modest impact of insurance on out-of-pocket payments may be partly explained by increased utilization of health care. In addition, the list of reimbursable items under insurance is not universal and expenditure caps exist for covered items. Hospitals are reported to routinely encounter drug shortages with insured patients purchasing medication from private pharmacies at their own expense (Somanathanet al., 2013; Tranet al., 2011)."70

As has been repeated throughout this, genocide and ecocide are interdependent processes. Herbicidal violence has caused immense damage to numerous ecosystems, with devastating consequences, the extent of which will likely never be fully known. Westing writes:

"Herbicidal decimation of a forest leads to site debilitation for a number of reasons. The nutrients released by the fallen foliage cannot be held to any great extent by the soil and are thus lost to that ecosystem. Such nutrient dumping is especially severe in the tropics and often prominently involves potassium, nitrogen and phosphorus (Huây et al. paper 4.A; Zinke, paper 4.C). As the trees die, the newly unprotected soil is subject to erosional loss - the more so the steeper the terrain - until the re-establishment of a new vegetational cover (a grass cover which, however, protects the soil less well than the former trees). Indeed, recent soil studies have revealed that soils on steep slopes that have been subjected to wartime spraying are, more than a decade later, still seriously depleted in nitrogen as well as in total organic matter content (Huây \& $\mathrm{Cu}$, paper 4.B).... The close association between an animal's geographic distribution (i.e., the animal's presence or absence) and its particular habitat requirements is a fundamental tenet of ecology. Indeed, this relationship is an especially tight one in tropical forests (Leighton, paper 3.C). Recent comparisons in South Viet Nam of unsprayed inland forest sites with comparable sites that had been multiply sprayed during the war, have been subjected to subsequent fires, and are now dominated by grasses abundantly confirm this relationship. For example, in two unsprayed forests 145 and 170 birds were recorded whereas in the destroyed forest (now grasslands) there were only 24 (Qúy et al., paper 3.A). Similar values for mammals were 30 and 55 in the two unsprayed sites, but only 5 in the comparable though previously sprayed site. Moreover, an examination of the mammalian species that comprise these numbers reveals that whereas most taxa of wildlife declined, the numbers of undesirable rodent species increased." (p. 18-19)

124000 ha (40 percent of total) of mangrove forests were "utterly devastated". This specific ecological destruction has proven to be particularly harmful in the long term, as mangrove forests not only are major carbon sinks, but are key in mitigating shoreline erosion and filtering 
water. The devastation of the war also led to the use of mangroves after reunification for reconstruction and fuel. By 1978, one of the regions, Can Gio, came under Ho Chi Minh City control and served as a site of wood production until 1991, when protections were put in place, turning it into a restoration site. However, with the increase in tourism (overall, with the notable exception of 2020), and related increases in development, restoration sites might be threatened. ${ }^{71}$ The material intensive development of Vietnam in the past few decades, in part related to the dependency on growth and exportation produced by the war, has increased pollution in ecosystems and hydrosystems specifically. ${ }^{72}$ Further, the establishment of protected zones while good public relations has also been a way to segment and control land use. This at times extends the span of areas whose resources are allowed to be expropriated, while disproportionately policing small scale appropriation of commons.

A less focused on aspect of environmental destruction during and resulting from American occupation is that of the Green Revolution. The Green Revolution was the 1950s and 60s agricultural technology shift with the same promises and realities as commodified fertilizers always bring: the elimination of hunger, with the actuality of metabolic rifts, rapidly decreasing soil fertility and biodiversity, along with poisoning to boot and indebtedness. As Vandana Shiva writes:

"For 10,000 years, farmers and peasants had produced their own seeds, on their own land, selecting the best seeds, storing them, replanting them, and letting nature take its course in the renewal and enrichment of life. With the Green Revolution, peasants were no longer to be custodians of the common genetic heritage through the storage and preservation of grain. The 'miracle seeds' of the Green Revolution transformed this common genetic heritage into private property, protected by patents and intellectual property rights. Peasants as plant breeding specialists gave way to scientists of multinational seed companies and international research institutions like CIMMYT and IRRI. Plant breeding strategies of maintaining and enriching genetic diversity and selfrenewability of crops were substituted by new breeding strategies of uniformity and nonrenewability, aimed primarily at increasing transnational profits and First World control over the genetic resources of the Third World." (p. 63) ${ }^{73}$

Since the introduction of commodity fertilizers to Vietnam in the 1960s, importation has increased dramatically, with most increases following the đổi mới reforms. This has been in combination with the dramatic increase in use of International Rice Research Institute's "high yield" seeds. In a 2006 paper, Jennifer Soong describes the farmers as "addicted" to both fertilizer and rice and identifies the imbalanced use of fertilizers to be one potential cause of the deterioration of soil. ${ }^{74}$ As Foster and Marx before him have argued, soil deterioration in relation to increased fertilizer use is a result of the inherently extractive condition of commodity production and commodity fertilizers, where the production of the fertilizer depends on the exploitation and expropriation of labors both human and nonhuman to create a profit, which depends on exponential growth.

In 2019, Cambodia imported more than 1.3 million tons of fertilizer and pesticide, an increase of $9 \%$ over the previous year. ${ }^{75}$ As of 2018 , the majority of Laotian farmers still use saved seeds, and use, relative to other nearby countries, lower amounts of fertilizer. Vietnam has banned the use of Round Up and is fighting to get Monsanto to pay for its role during the war $^{76}$. Since 2001, however, Vietnam has expanded market 'liberalization', and begun plans to 'modernize' the agricultural sector. ${ }^{77}$ It has also vastly expanded fertilizer production, 
which has led to decreases in importation. Although initially 'high yield' agriculture led to significant increases in yield, in Vietnam it seems this increase has tapered out over time.

\section{Weaponizing Primarily white male Rage and Rape as Standard Operating Procedure}

The genocidal white supremacy of the U.S. army conditioned those within the institution to take the trauma and violences forced upon them out on racialized and dehumanized 'enemies,' rather than identifying their common oppressor as the interdependent systems which manufactured their own precarity and exposure to violence. More, it emboldened and recruited those who had already internalized supremacy and a desire to dominate. The state recognized the capacity for hatred fueled young bodies to destroy and expanded this capacity through the constant violation of consent, individual, and safety embedded in the experience of the total institution. The army also capitalized on the rupture of a trauma metabolism, namely, by drugging soldiers with amphetamines and opiates in what Nick Land calls a "pharmacological war," 78 the army was able to displace the normal responses to the trauma of the war into the veteran's futures, increasing the violence the soldiers not only could withstand but wanted to inflict, and likely further limiting some soldiers capacity to empathize with the people they slaughtered, tortured, raped, sprayed, bombed, and burnt.

"In Viet Nam, the U.S. Military Command made rape 'socially acceptable'; in fact, it was unwritten, but clear, policy. Systematic mass rape was a policy implemented by consistently covering up reported rapes and by making it clear to GI's that they had no real need to fear punishment." (p. 61)

Bergman goes on to connect rape and sexed bioessentialist narratives of hierarchy of labor kinds and natural inclination towards reproduction to the expropriation of labor reproducing the labor force, writing "women's labor in the home supplies the economy with billions of hours of free labor-labor necessary to produce and maintain the nation's work force. Employer's profits would be a lot lower if they had to pay even minimum wage for all the hours of work done by the wives of their employees — work which makes it possible for these employees to be available and efficient at the job"

Men who voluntarily enlisted out of a desire to prove their manhood and those coerced into joining the forces as a 'better alternative' to incarceration, or through the promise of an income and college, alike were subjected to the violence of the "he-man-making machine" (Bergman p. 65), psychologically and physically abused into hating any potential for woman within the naturally fluid self. Making men is not a process of recognizing the identification with a gender but demanding the extraction of anything which a higher up or peer accuses is womanly. This encourages self and group policing to escalate violence, which makes for more "efficient" genocide, femicide, and ecocide. It also offers an outlet for the constant and produced trauma of the military: the bodies and minds of people perceived as feminine. Soldiers are taught that their trauma matters only insofar as it can be used to invalidate the violences they do to others, as in the perspective, 'yeah, well I went through worse and I got through it'.

The violences inflicted upon soldiers were unquestionably real, and extremely traumatizing for some. William Blum writes about one of the US Navy classes:

"Students were supposedly learning about methods of 'survival, evasion, resistance, and escape' which they could use as prisoners of war. There was in the course something of survival in a desert, where students were forced to eat lizards, but the naval officers and cadets were also subjected to beatings, jarring judo flips, 'tiger cages'-hooded and 
placed in a 16-cubic-foot box for 22 hours with a coffee can for their excrement and a torture device called the 'water board': the subject strapped to an inclined board, head downward, a towel placed over his face, and cold water poured over the towel; he would choke, gag, retch, and gurgle as he experienced the sensation of drowning, just as was done to Vietcong prisoners in Vietnam, along with the tiger cages.

A former student, Navy pilot Lt. Wendell Richard Young, claimed that his back was broken during the course and that students were tortured into spitting, urinating, and defecating on the American flag, masturbating before guards, and on one occasion engaging in sex with an instructor." p 129

The phrasing "engaging in sex" is incorrect—what Young is describing is rape. And the rape of soldiers was fairly commonplace, but rape just isn't frequently part of the historical discussions of war. As Nick Turse writes:

"Veterans, their advocates, and their defenders often tell us it's never okay to ask if a soldier or marine killed somebody "over there." But if veterans refuse to offer up unsanitized accounts of their wartime experiences and it's improper for us to ask what they did, how can civilians be faulted for failing to understand war?

To set the historical record straight, I've traveled across the globe, walked into people's homes, and asked them questions to which, in a better world than ours, no one should have to know the answers. I've asked elderly Vietnamese to recount the most horrific traumas imaginable. I've induced rivers of tears. I've sat impassively, taking notes as an older woman, bouncing her grandchild on her knee, told me what it was like to be raped with an American weapon.

...we'll never know the whole truth of sexual assault in Vietnam. The men involved in wartime sex crimes - in raping Vietnamese women, in sodomizing them, in violating them with bottles and rifle muzzles, in sexually assaulting American women, in raping American men - have mostly remained silent about it." 79

Spouses, partners, and families of veterans also were subjected to these violences. Like cops, veterans are more likely than civilian counterparts to physically, emotionally, and sexually abuse their partners. One study analyzing intimate partner \& general violence among combat veterans at a PTSD clinic, involving $236 \mathrm{men}, 63 \%$ of whom had served in Vietnam, found that of the 161 partnered veterans, $33 \%$ had been physically abusive toward their partner in the last year, and $91.3 \%$ had been psychologically abusive towards their partner. ${ }^{80}$

For many of the men, the experiences of raping, mass murdering, ecological destruction, and communal destruction were not, either in the moment or long term, traumatic, but rather empowering, pleasurable, or stress relieving. According to the VA, about $30 \%$ of Vietnam Veterans have had PTSD in their lifetime. If this is an accurate representation that suggests about $70 \%$ of Veterans did not have PTSD as a result of the war. Bergman points out, rape was frequently

"Humiliated GIs [taking] revenge by humiliating women:

One thing that was more or less a joke... and it would get a laugh every time from somebody, was if we were moving through a village and there was a woman present. Her clothes, at least the top half were just ripped [off] ..." (p. 71)

Most of all, Vietnamese (and Laotian, and Cambodian, and Hmong, and numerous other groups) women and girls (as well as those perceived as such) bore the overwhelming majority of the violences by these men and have received the least amount of self-directed representation or reparation. The state-sanctioned rape and GI entitlement to women's (and perceived women, and 
children, and people more broadly) bodies not only involved the mass traumatization of these targets, but it perpetuated and normalized a culture of violence against targeted, racialized women. As Federici (and so many others) have described, this form of violence is specifically related to the labor subjugation of women. According to Bergman, the North Vietnamese resisted this, framing the violence against women as American aggression and instilling a policy of: "[fighting] against the traditional shame and prejudice against women who have been raped. Vietnamese women often transform their shame into fighting energy. Le Thi Hon Gam, a heroine of the PLAF, became a guerrilla when she was 16. She insisted on being allowed to take up arms after witnessing the rape/murder of her best friend. By the time Gam died in combat, at age 19, she had killed 26 enemy troops. Other women respond to rape with their own individual acts of resistance. The New Yorker magazine, April 15, 1972, reported the practice of 'deranged war widows deliberately squatting to relieve themselves in front of hotels where Americans stay.' Some women may silently guard their hatred and join the struggle at a later time." (p. 73)

Although Bergman presents an image of women not being outcast for the violences done to them, it's worth noting that this may be an example of a glossier image than the reality faced by some survivors. Or, perhaps, this may have applied more to North Vietnam than liberated areas in the South. In South Vietnam, at least some women, and children of rape, did face stigmatization, ostracization, and harassment for having been abused. Tran Thi Ngai has spoken out about her experiences being raped by U.S. aligned South Korean soldiers, and the subsequent social abuse she faced. She says: "Afterwards I cried for days but my parents just shouted at me. They thought I had had sex with him of my own free will. No-one would believe me." 81 Although the Independent article blames Confucianism for the ostracization, the men who committed these war crimes, as encouraged by the military, and like their French predecessors, blamed the women and children they violently raped for wanting it. Like the internalization of oppression described by Frantz Fanon, the internalization of gaslighting (in its most extreme sense), woman hating, and victim blaming should not be dismissed, minimized, or blamed on the population subjected to it.

Sexual violence also came in the form of precarity as a result of displacement. Writes Bergman:

"At the height of U.S. troop occupation, there were four hundred thousand prostitutes in South Viet Nam, nearly one for every GI. These prostitutes are the end product of a process that began when Diem started rounding up his opponents and forcing them into concentration camps in 1956. ... By 1973, as a result of forced urbanization, bombings, and defoliation making the land barren, peasants had swollen the population of Saigon to over 4 million. In 1954, the entire population of Saigon was only four hundred thousand. The United States Senate Subcommittee on Refugees estimates that between 1965 and 1973 , more than ten million people were forced to flee their villages." (p. 80)

Sex work, like any work, is as violent as the material conditions under which it is done. However, it's also important to note that much of this wasn't sex work - it was rape. Just as the reproduction of a dependent labor force demands a huge amount of both care labor and violence, the production of dependency and difference itself demands an incalculable amount of destruction and displacement. Robinson discusses displacement and migration in the formation of European capitalism as such:

"The important meaning is that this form of enlisting human reserves was not peculiar to military apparatus but extended throughout Europe to domestic service, handicrafts, 
industrial labor, the ship- and dock-workers of merchant capitalism, and the field laborers of agrarian capitalism. There has never been a moment in modern European history (if before) that migratory and/or immigrant labor was not a significant aspect of European economies." p 23

The forced urbanization, in part, might then be seen as an army satisfying the desires of soldiers too, by increasing even further the power soldiers were able to exercise over those they wanted to exert power over. Much broader than that, the violent and completely destructive (As in, the literal destruction of communities) displacement policies during the war disconnected people from prior forms of sustenance and sustainable reproduction. In the long term, this made the assimilation of people into wage labor as well as the enslavement of people more possible. As the majority of those killed were men, this placed a higher burden on women to enter the workforce. This has been framed by the IMF as inspiring, drawing connections to Rosie the Riveter, rather than a grotesque exploitation of the women and people of Vietnam. ${ }^{82}$ The work by Teerawichitchainan et al. indicates that although market reforms have not significantly deteriorated gender equality in the home, that gendered labor divisions remain stark:

"Wives by far do most of these laborious domestic tasks. Despite slight increase of involvement among husbands from the renovation cohort and closing gaps between the North and the South, much smaller proportions of men are reported to contribute to household chores than to childcare tasks. Further, husband's steadily increased participation in household budget management should be interpreted with caution. Instead of indicating gender egalitarianism, husband in recent cohorts might have wanted to manage household budget more than earlier cohorts because they would like to be in control of family financial matters particularly when household disposable income has doubled or tripled after the market reform." (p. 22) ${ }^{83}$

They also affirm that the socialist policies surrounding gender egalitarianism actually increased the responsibility on women.

"As a good socialist woman, wives were encouraged to uphold three virtues which include responsibilities for the family, for production and work, and for the national defense. Such expectations resulted in placing multiple burdens on Vietnamese women rather than empowering them (Pham 1999)." (p.21)

The constructed reliance on development and growth has continued in some places the coercive assimilation of people into wage labor, disproportionately impacting minority communities, and disproportionately women (or those perceived as women) considering the within these communities, through ecological destruction resulting directly from production and construction, as well as through the broader impacts of global production and supply chains. In one example, a combination of land-use restrictions, the construction of road 14B, and climate change, have significantly impacted people in the Co Tu community in Cady Commune, which used to be self-sufficient and without need for cash. Over the past few decades, facing resulting food insecurity and new fees for things like tuition and motorbikes, people in the community have had to begin to produce to sell, rather than to sustain. This has resulted in shifting gender dynamics and labor divisions. In group discussions, there were two main responses to the changes, split largely by gender (or perceived gender). The response mostly given by women was that life was worse, because of weather changes, price increases, and soil degradation. The response mostly given by men was that things had gotten better because of increased access to entertainment and technologies. To put it too simply, the responsibilities of sustaining the family 
have increased for those perceived by the researchers as women and decreased for those perceived by the researchers as men. ${ }^{84}$

One study by the UN Population Fund, involving 6,000 women between the ages of 15 and 64 across Vietnam found that $32 \%$ of the women had suffered abuse within the year and 62.9 percent had suffered one or more kinds of abuse from male partners. ${ }^{85}$ In Cambodia, while domestic and gendered violence are possibly on the decline, victim blaming narratives are common, and that survivors feel they are to blame if they don't do enough housework. ${ }^{86}$ A 2014 UN study on violence against women in Laos found that $58 \%$ of women and $49 \%$ of men thought that violence was justified if the women didn't obey gender roles, and that $15.3 \%$ of women had experienced physical or sexual abuse. Yoshioka et al., studying family violence in Chinese, Cambodian, Korean, South Asian, and Vietnamese communities in 2000 in Massachusetts, reported that:

"A Vietnamese focus group recognized that the father is the head who supports the family and thus has the right to "teach" his wife, control her and abuse her. Because men can find work more easily, their wives are financially dependent. Women do not speak up against their husbands because they are afraid that their husbands will leave. She must tolerate his abuses, affairs and drinking. A Cambodian focus group felt that when Cambodians learn of an abusive situation, they are apt to believe that the woman deserved it and will blame the woman for breaking up the family. Men feel that they have lost power and control because their value as the head of household is diminished as a result of their wives and children's employment. They also commented that posttraumatic stress disorder might play a role." 87

\section{Loss and 'Sacrifice"'}

A few months before the liberation of Saigon, A. Denny Ellerman wrote a memo to then Secretary Kissinger, in which he discusses the costs associated with necessary aid to the neocolonial South Vietnamese state for the next decade. In this, he writes

"The development of a more self-reliant South Vietnamese economy depends on two conditions: (1) adequate economic aid to support the level of military expenditures and to provide investment for the employment of idle urban labor in the countryside, and (2) security conditions that permit reverse migration. Economic aid should be adopted for the former, while military aid conditions the latter. The South Vietnamese economy is equally dependent upon both." (his underlining)

The interagency memo responding to this elaborates as to the specific expectations of needed aid, with the CIA expecting an average of $\$ 700$ million annually, Department of Treasury estimating \$500 million annually, and the Department of State expecting that security conditions would deteriorate and require significantly more than $\$ 700$ million annually. The North Vietnamese capture of Saigon allowed for another path, one which the U.S. had been predicting for a while, losing. Or, a narrative of loss, by which I mean not to discredit or diminish the North Vietnamese successes, but rather to acknowledge that the narrative of loss functioned politically in the U.S. to seal the war into the past tense, to separate it as something that happened, which minimized the ongoing violences begun during the war and as a result of actions after the war. Loss meant not having to spend a decade paying for the uncertain survival of a neo-colony, it

\footnotetext{
${ }^{1}$ referring to Nkrumah
} 
meant allowing crises resulting from genocide and ecocide to fall on the shoulders of an establishing state while continuing to engage in economic warfare through a trade embargo. Recalling Robinson's point that capitalism depends on continuous flows of migrant labor, loss also meant an influx of precarious racialized refugees who would take very low paying jobs to survive.

Further, the U.S. was able to continue to indirectly wage war on unified Vietnam through support for the Khmer Rouge. "Still-incomplete" data indicates that the genocidal U.S. bombing campaigns lasted from 1965 to 1973, during which 2,756,941 tons of ordinance were dropped on Cambodia, which for reference is about the size of Oklahoma. ${ }^{88}$ Although the 1973 year might seem to imply that the bombings ended with the Paris Peace Accords, they actually increased in intensity significantly afterwards. Ben Kiernan places the number of people murdered by these attacks between 50,000 and 150,000. In 1970 the U.S. had backed a right-wing coup ousting Norodom Sihanouk and installing Lon Nol in his place. Combined with the bombing, these greatly expanded the support for the previously nominal Khmer Rouge, who used these war crimes as recruitment tools. Immediately after Vietnamese reuinification, the U.S. began policies intended to isolate Vietnam and minimize its potential for successful reform, putting in place a trade embargo, and refusing to pay the $\$ 3.25$ billion in reparations that Nixon had agreed upon. When the Khmer Rouge ousted Lon Nol in 1975, the U.S. saw this as an opportunity to isolate Vietnam further, and encouraged China and Thailand to support Cambodia financially and militarily. ${ }^{89}$

The genocidal actions of the Khmer Rouge were well known to the U.S., and while the assimilation and mass murder of Cham and ethnic Chinese may have largely been motivated, according to Liai Duong, on misconceptions of class and at times rebellion against assimilationist order, the genocidal actions against Kinh people were largely motivated by antiVietnamese sentiment. ${ }^{90}$ In 1978, after multiple Cambodian attacks on the border between the two countries, resulting in thousands of deaths, Vietnam invaded Cambodia and by 1979 ousted the Khmer Rouge. At this point, the U.S. decided to officially back the Khmer Rouge, ensuring that China provided $\$ 100$ million in military aid yearly through the 80 s, seating them at the UN, and refusing to call the Khmer Rouge genocide a genocide until 1989.

Vietnam began the 'liberalization' of the economy in 1986. The U.S. lifted the trade embargo in 1994 and seven years later, after a long series of negotiations, the two countries signed a free trade agreement in 2001. Since then, trade has grown substantially, as has Vietnamese overproduction, exportation, and the coffers of major multinationals profiting off of underpaid and unpaid labor. Vietnam has signed onto 13 free trade agreements, and another 12 under consultation or in negotiations. All of these have stipulations worth diving into. Laos has 9 FTAs, and 7 under consideration or negotiations. Cambodia has 8 FTAs, with 9 proposed or under negotiation. ${ }^{91}$ Over the past few decades, Vietnam has sold off large amounts of its stateowned enterprises, going from 10,000 fully owned by the state to less than 1,000 fully owned and 3,000 partially owned..$^{92}$

\section{Conclusion}

This thesis is an exceptionally incomplete attempt to begin to grapple with the legacies of colonialism in Vietnam, Cambodia, and Laos, to interrogate the genocidal and ecocidal policies not as aberrations, or merely 'part of the fight against communism', or a blight on the psyche of America, but as a conscious extension of the white imperialist capitalism at the core of the U.S. 
state. Further, it is an attempt begin to dismantle the separation of time which I believe pervades discussions of ongoing exploitation and expropriation in these countries. I also want to reiterate the aim of this is not to focus criticism on Vietnam, Cambodia, or Laos, in part because I do not know enough to do so, in part because of where I am situated - the United States and the stratum of billionaires it works with are an ongoing and imminent threat to the earth and the people of earth, with violence, as has been for centuries, distributed unequally onto those who are labeled disposable. In the case of Vietnam, there is evidence that the government has attempted to use it's "certain area of maneouvre" to improve the lives of its people. Identifying the creation of the conditions for forcible capitalist assimilation, I believe, is important in recognizing the long term aims and outcomes of militarism, genocide, and ecocide, which so often seem to be viewed as atrocities alone, separated from what came 'before' or what came 'after'. I am still learning that perhaps there is no before or after.

I also want to acknowledge a few pieces that I haven't written about, that are worth attention. I haven't talked about the concentration camps of the strategic hamlet program, where people were violently relocated and forced to construct their own camps, or Phạm Ngọc Thảo, the communist spy in charge of the implementation of the SHP who learned that the camps were increasing anti-imperialist sentiment and encouraged the speeding up on the process as well as choosing villages where communists already were to sabotage the program and drive recruitment. I haven't talked about how the impacts of coronavirus-related travel declines relate to neocolonial tourism, or Vietnam's success with containing coronavirus, and how pro-capitalist outlets have alternately demonized this as authoritarian, dismissed the success, or idolized the perceived authoritarianism. I haven't discussed automation, or the Special Economic Zones. I have focused largely on Vietnam, which is unquestionably limiting (and which reproduces existing disproportionalities of attention). There's so much more that I have missed, and I do not know all I have missed.

Racialized timelines condensed into value/worth hierarchy permeate and are reproduced through colonized spaces and institutions, including the one for which I'm writing this thesis. There's an expectation at the end of theses for a clean, technocratic policy proposal to address what has been discussed prior to that point, and I can't give that. In part, I can't give that because there can't be complete restoration. To consider Renee Heberle's analysis of Adorno's negative dialectics ${ }^{93}$, there is an unfixable suffering that cannot be eliminated or completely understood through synthesis. In part, I can't give a clear proposal because I am not in any of the groups harmed by this war. In part, I can't give a policy proposal because even the minimal policies that have been proposed have been ignored by the U.S. imperial state and will continue to be ignored as long as the state is able to do so. In part, I can't give a policy proposal because things like reparations, when co-opted into policy, end up existing within the structure of aid driven power.

Rather, I believe it is necessary to work to create the world abolitionists have been, for centuries, fighting for and conceptualizing. To continue the work to abolish slavery, wage slavery, prisons, police, borders, the military, the school to prison pipeline, the growth based economic order. To abolish the white supremacist, hierarchical, colonially and bureaucratically constructed Family structure. We need to free prisoners and cease the occupation of all military bases. We need to distribute food and housing by need, restore localized food systems, and make healthcare accessible and free for all. We need to cancel debts. We need to end the ongoing wars in Afghanistan, Somalia, Syria, Yemen, Iraq, Libya, and Niger, and end deadly sanctions in Venezuela, Iran, Syria, Cuba, and on. 
The U.S., and other settler colonial states leading ecological destruction through capital accumulation and ongoing indigenous displacement need to reject green capitalism and ecological modernization. As the crises accumulate, governments may be forced into minor concessions, like carbon neutrality through the purchasing of carbon credits, or the mass expansion of 'sustainable' commodified energy which in practice depend on violent displacement, ecological destruction, and extraction. Or the cancelation of a measly $\$ 10 \mathrm{k}$ of some student's debt. Or a federal minimum wage increase. Or police 'reforms' which amount to increased funding for police, surveillance, and criminalization (as has been done for decades). These are never enough.

How do we create a world where survival isn't dependent upon continuous growth? What conditions need to exist to cease those cycles of destruction, to maximize agency and autonomy? How do we repair rifts? What rifts are irreparable? The U.S. killed millions of people, destroyed ecosystems, manufactured the conditions for ongoing extraction, exploitation and expropriation. The U.S. continues to kill, imprison, steal, and disable, to determine whose bodies are worth saving and whose are slated for slaughter. Who are conditioned into subservience, starved into labor, or murdered for profit? No explanation I give can encapsulate the harm done, and even with all the potential ways of stopping ongoing violence, there can be no "whole" restoration. Given the right conditions, some trauma can heal, to a degree, over time, but life taken cannot be given back.

\section{Bibliography}

${ }^{1}$ Fuller, Thomas. "Capitalist Soul Rises as Ho Chi Minh City Sheds its Past." New York Times Company, last modified Jul 20.

2 "U.S. Spent \$141-Billion in Vietnam in 14 Years." 1975.New York Times (1923-Current File), May 01, 20.

http://stats.lib.pdx.edu/proxy.php?url=http://search.proquest.com.proxy.lib.pdx.edu/docvi ew/120441497?accountid=13265.

${ }^{3}$ Obermeyer, Ziad, Christopher J L Murray, and Emmanuela Gakidou. "Fifty Years of Violent War Deaths from Vietnam to Bosnia: Analysis of Data from the World Health Survey Programme." Bmj 336, no. 7659 (2008): 1482-486. doi:10.1136/bmj.a137.

${ }^{4}$ Viet, Thanh Nguyen. 2020. "Vietnamese Lives, American Imperialist Views: [the Arts/Cultural Desk]." New York Times, Jun 25. http://stats.lib.pdx.edu/proxy.php?url=http://search.proquest.com.proxy.lib.pdx.edu/docvi ew/2416807239? accountid=13265. 
${ }^{5}$ Nkrumah, Kwame. "Introduction." Neo-Colonialism, the Last Stage of Imperialism by Kwame Nkrumah. Accessed November 18, 2020.

https://www.marxists.org/subject/africa/nkrumah/neo-colonialism/introduction.htm.

6 "Vietnam Continues to Reduce Poverty, According to WB Report." World Bank. April 5, 2018. Accessed November 18, 2020. https://www.worldbank.org/en/news/pressrelease/2018/04/05/vietnam-continues-to-reduce-poverty-according-to-world-bankreport.

7 "Cambodia: Reducing Poverty and Sharing Prosperity." World Bank. October 29, 2019. Accessed November 18, 2020. https://www.worldbank.org/en/results/2019/10/30/cambodia-reducing-poverty-andsharing-prosperity.

${ }^{8}$ Warr, Peter, Sitthiroth Rasphone, and Jayant Menon. "Two Decades of Declining Poverty but Rising Inequality in Laos." Wiley Online Library. June 19, 2018. Accessed November 18, 2020. https://onlinelibrary.wiley.com/doi/abs/10.1111/asej.12147.

${ }^{9}$ Nathan, David. "The Truth behind Cambodia's Inequalities." New Internationalist. July 05, 2017. Accessed November 18, 2020. https://newint.org/features/webexclusive/2014/09/12/cambodia-economic-inequality.

${ }^{10}$ Thi Quynh Hoa, Vu, and Andrew Wells-Dang. "Shrinking Opportunities: Social Mobility and Widening Inequality in Vietnam." UNRISD. May 20, 2019. Accessed November 18, 2020.

https://www.unrisd.org/80256B3C005BE6B5/search/C0838EC429923FAAC125840000 323191.

11 "UNdata | Record View | External Debt Stocks, Total (DOD, Current US\$)." United Nations. Accessed November 18, 2020. http://data.un.org/Data.aspx?d=WDI\&f=Indicator_Code:DT.DOD.DECT.CD;Country_C ode:KHM,LAO,VNM\&c=2,4,5\&s=Country_Name:asc,Year:desc\&v=1.

${ }^{12}$ Silvia Federici; From Commoning to Debt: Financialization, Microcredit, and the Changing Architecture of Capital Accumulation. South Atlantic Quarterly 1 April 2014; 113 (2): 231-244. doi: https://doi.org/10.1215/00382876-2643585

${ }^{13}$ Blomberg, Matt, and Mech Dara. "Land to Lose: Coronavirus Compounds Debt Crisis in Cambodia." Reuters. September 21, 2020. Accessed November 19, 2020. https://www.reuters.com/article/us-cambodia-finance-loans/land-to-lose-coronaviruscompounds-debt-crisis-in-cambodia-idUSKCN26C02S.

${ }^{14}$ OECD. Aid (ODA) Disbursements to Countries and Regions [DAC2a]. Accessed November 19, 2020. https://stats.oecd.org/Index.aspx?DataSetCode=Table2A. 
15 "US to Provide Cambodia with \$56 Million in Development Aid." ABC News. June 26, 2020. Accessed November 19, 2020. https://abcnews.go.com/US/wireStory/us-providecambodia-56-million-development-aid-71474954.

16 "The U.S. Government Provides Immediate Assistance in Response to Widespread Flooding in Cambodia." U.S. Embassy in Cambodia. October 17, 2020. Accessed November 19, 2020. https://kh.usembassy.gov/the-u-s-government-provides-immediate-assistance-inresponse-to-widespread-flooding-in-cambodia/.

17 Turton, Shaun, and Mech Dara. "Cambodia Floods Put Spotlight on Risk of Trading Lakes for Land." Nikkei Asia. October 26, 2020. Accessed November 19, 2020. https://asia.nikkei.com/Economy/Natural-disasters/Cambodia-floods-put-spotlight-onrisk-of-trading-lakes-for-land.

18 "Cambodia (KHM) Exports, Imports, and Trade Partners." Observatory of Economic Complexity. Accessed November 19, 2020. https://oec.world/en/profile/country/khm?tradeScaleSelector1=tradeScale2.

19 "Cambodia's Garment Manufacturing Industry." ASEAN Business News. November 11, 2018. Accessed November 19, 2020. https://www.aseanbriefing.com/news/cambodias-garmentmanufacturing-industry/.

${ }^{20}$ Reed, John. "Laos Faces Sovereign Default as Forex Reserves Dip below \$1bn." Financial Times. September 03, 2020. Accessed November 21, 2020. https://www.ft.com/content/dc3f5981-4fd9-4e3a-9824-5b9ddf70735e.

${ }^{21}$ Strangio, Sebastian. "Laos Stumbles Under Rising Chinese Debt Burden." - The Diplomat. September 07, 2020. Accessed November 21, 2020. https://thediplomat.com/2020/09/laos-stumbles-under-rising-chinese-debt-burden/.

22 Tan, Weizhen. "China under Pressure to Write off Loans as Countries Struggle to Repay Debt during Coronavirus Crisis." CNBC. May 11, 2020. Accessed November 21, 2020. https://www.cnbc.com/2020/05/11/belt-and-road-china-may-have-to-write-off-loans-ascountries-struggle-to-pay.html.

23 "Laos Exports, Imports, and Trade Partners." Observatory of Economic Complexity. Accessed November 19, 2020. https://oec.world/en/profile/country/lao

24 Xiaoxia. "Energy Sector Powering Growth in Laos." Xinhua. Accessed November 21, 2020. http://www.xinhuanet.com/english/2019-04/08/c_137959657.htm.

${ }^{25}$ Ratcliffe, Rebecca. "Cambodia Scraps Plans for Mekong Hydropower Dams." The Guardian. March 20, 2020. Accessed November 21, 2020. https://www.theguardian.com/world/2020/mar/20/cambodia-scraps-plans-for-mekonghydropower-dams. 
${ }^{26}$ Moran, Emilio, Maria Claudia Lopez, Nathan Moore, Norbert Muller, and David Hyndman. "Sustainable Hydropower in the 21st Century." PNAS 115, no. 47 (September 25, 2018): 11891-1898.

27 Vietnam Exports, Imports, and Trade Partners." Observatory of Economic Complexity. Accessed November 19, 2020. https://oec.world/en/profile/country/vnm

${ }^{28}$ Bateman, Milford. Why Doesn't Microfinance Work?: The Destructive Rise of Local Neoliberalism. London: Zed Books, 2010.

${ }^{29}$ Connett, Wendy. "Where the Ultra-Wealthy Live in the United States." Investopedia. August 29, 2020. Accessed November 20, 2020. https://www.investopedia.com/articles/financialadvisors/062515/where-ultrawealthy-live-america.asp.

${ }^{30}$ Toward Fair Compensation in Vietnam. Report. May 2019. https://www.fairlabor.org/sites/default/files/documents/reports/vietnam_wagereport_final .pdf.

${ }^{31}$ Phong, Hoang. "91 Labor Strikes Reported in Vietnam as Covid-19 Hits Businesses VnExpress International." VnExpress International - Latest News, Business, Travel and Analysis from Vietnam. June 25, 2020. https://e.vnexpress.net/news/news/91-laborstrikes-reported-in-vietnam-as-covid-19-hits-businesses-4120868.html.

32 "Goal 2: Zero Hunger - United Nations Sustainable Development." United Nations. Accessed November 19, 2020. https://www.un.org/sustainabledevelopment/hunger/.

${ }^{33}$ Robinson, Cedric J. Black Marxism: The Making of The Black Radical Tradition. 2nd ed. University of North Carolina Press, 2000.

${ }^{34}$ Quijano, Aníbal. "Coloniality of Power and Eurocentrism in Latin America." International Sociology 15, no. 2 (2000): 215-32. doi:10.1177/0268580900015002005.

${ }^{35}$ Collins, Patricia Hill. Black Feminist Thought: Knowledge, Consciousness and the Politics of Empowerment. Hyman, 1990.

${ }^{36}$ Crenshaw, Kimberle. "Mapping the Margins: Intersectionality, Identity Politics, and Violence against Women of Color." Stanford Law Review 43, no. 6 (July 1991): 1241-299.

${ }^{37}$ Mbembé, Achille. "Necropolitics." Translated by Libby Meintjes. Public Culture 15, no. 1 (2003): 11-40.

${ }^{38}$ Washington, Harriet. Medical Apartheid The Dark History of Medical Experimentation on Black Americans from Colonial Times to the Present. Doubleday, 2007.

${ }^{39}$ Omolade, Barbara. "Hearts of Darkness." In Words of Fire: An Anthology of African-American Feminist Thought, edited by Beverly Guy-Sheftall. New York, NY: New Press, The, 2011. 
${ }^{40}$ MacKinnon, Catharine A. Toward a Feminist Theory of the State. Cambridge, MA: Harvard University Press, 1991.

${ }^{41}$ Federici, Silvia. Caliban and the Witch: Women, the Body and Primitive Accumulation. New York: Autonomedia, 2014.

42 Foster, John Bellamy. "Marx, Value, and Nature." Monthly Review, 2018, 122-36. doi:10.14452/mr-070-03-2018-07_6.

${ }^{43}$ Bergman, Arlene Eisen. Women of Vietnam. San Francisco, CA: Peoples Press, 1975.

${ }^{45}$ Chapuis, Oscar. The Last Emperors of Vietnam: From Tu Duc to Bao Dai. Westport, CT: Greenwood Press, 2000.

46 Karine Delaye (2003) Slavery and Colonial Representations in Indochina from the Second Half of the Nineteenth to the Early Twentieth Century, Slavery and Abolition, 24:2,129142, DOI: $10.1080 / 01440390308559160$

${ }^{47}$ Bửu Lâm, Trương. Colonialism Experienced: Vietnamese Writings on Colonialism, 19001931. Ann Arbor, MI: University of Michigan, 2003.

${ }^{48}$ Proschan, Frank. "'Syphilis, Opiomania, and Pederasty": Colonial Constructions of Vietnamese (and French) Social Diseases." Journal of the History of Sexuality 11, no. 4 (2002): 610-36. doi:10.1353/sex.2003.0043.

${ }^{49}$ Firpo, Christina. "Crises of Whiteness and Empire in Colonial Indochina: The Removal of Abandoned Eurasian Children from the Vietnamese Milieu, 1890-1956." Journal of Social History 43, no. 3 (2010): 587-613. Accessed November 18, 2020. http://www.jstor.org/stable/20685426.

${ }^{50}$ Roberts, Dorothy E. "Black Mothers, Prison, and Foster Care." Restorative and Responsive Human Services, 2019, 116-26. doi:10.4324/9780429398704-8.

${ }^{51}$ Akee, Randall. "40 Years Ago We Stopped the Practice of Separating American Indian Families. Let's Not Reverse Course." Brookings. October 12, 2018. Accessed November 20, 2020. https:/www.brookings.edu/blog/up-front/2018/10/11/40-years-ago-westopped-the-practice-of-separating-american-indian-families-lets-not-reverse-course/.

52 Sawyer, Wendy. "Youth Confinement: The Whole Pie 2019." Youth Confinement: The Whole Pie 2019 | Prison Policy Initiative. Accessed November 20, 2020. https://www.prisonpolicy.org/reports/youth2019.html.

53 Turse, Nick. Kill Anything That Moves: U.S. War Crimes and Atrocities in Vietnam, 19651973. New York, NY: Picador, 2013. 
${ }^{54}$ Blum, William. Killing Hope: US Military and CIA Interventions since World War II. Londres: Zed Books., 2014.

${ }^{55}$ Weinstein, Franklin B. "Vietnam's Unheld Elections." https://ecommons.cornell.edu/bitstream/handle/1813/57528/060.pdf?sequence=1\&isAllo wed $=\mathrm{y}$.

${ }^{56}$ Chapman, Jessica M. CAULDRON OF RESISTANCE: Ngo Dinh Diem, the United States, and 1950s Southern Vietnam. CORNELL University Press, 2018.

${ }^{57}$ Marshall, Jonathan. "Dirty Wars: French and American Piaster Profiteering in Indochina, 1945-75." The Asia-Pacific Journal: Japan Focus. Accessed November 21, 2020. https://apjjf.org/2014/12/32/Jonathan-Marshall/4160/article.html.

58 "Hmong Timeline." Minnesota Historical Society. Accessed November 22, 2020. https://www.mnhs.org/hmong/hmong-timeline.

59 "Hmong: Data on Asian Americans." Pew Research Center's Social \& Demographic Trends Project. December 31, 2019. Accessed November 22, 2020. https://www.pewsocialtrends.org/fact-sheet/asian-americans-hmong-in-the-u-s/.

${ }^{60}$ Coates, Karen J. Eternal Harvest: The Legacy of American Bombs in Laos. San Francisco, CA: ThingsAsian Press, 2013.

${ }^{61}$ Convery, Padriac. "An Uphill Battle: 80 Million Unexploded Bombs Still to Clear in Laos." South China Morning Post. November 19, 2018. Accessed November 22, 2020. https://www.scmp.com/magazines/post-magazine/long-reads/article/2173220/200-yearsgo-laos-cleared-unexploded-us-bombs.

${ }^{62}$ Institute of Medicine (US) Committee to Review the Health Effects in Vietnam Veterans of Exposure to Herbicides. Veterans and Agent Orange: Health Effects of Herbicides Used in Vietnam. Washington (DC): National Academies Press (US); 1994. 3, The U.S. Military and the Herbicide Program in Vietnam. Available from: https://www.ncbi.nlm.nih.gov/books/NBK236347/

63 "Bombing Missions of the Vietnam War." ArcGIS StoryMaps. Accessed November 21, 2020. https://storymaps.esri.com/stories/2017/vietnam-bombing/.

${ }^{64}$ Weisberg, Barry. Ecocide in Indochina; the Ecology of War. Canfield Press, 1970.

${ }^{65}$ Grandin, Greg. "In Vietnam War US Deliberately Bombed Hospitals." History News Network. Accessed November 21, 2020. http://hnn.us/article/160863.

${ }^{66}$ Dainton, Deborah. "The Vietnamese Association for Victims of Agent Orange." MSAVLC. October 21, 2105. Accessed November 19, 2020. http://msavlc.org/the-vietnameseassociation-of-victims-of-agent-orange-vava/. 
${ }^{67}$ Palmer, Michael, Cuong Viet Nguyen, Sophie Mitra, Daniel Mont, and Nora Ellen Groce. "Long-lasting Consequences of War on Disability." Journal of Peace Research 56, no. 6 (2019): 860-75. doi:10.1177/0022343319846545.

${ }^{68}$ Vijayasingham, Lavanya, Veloshnee Govender, Sophie Witter, and Michelle Remme. "Employment Based Health Financing Does Not Support Gender Equity in Universal Health Coverage." The BMJ. October 27, 2020. Accessed November 21, 2020. https://www.bmj.com/content/371/bmj.m3384.

${ }^{69}$ World Health Organization. Accessed November 21, 2020. https://apps.who.int/nha/database/ViewData/Indicators/en.

${ }^{70}$ Palmer, Michael. "Inequalities in Universal Health Coverage: Evidence from Vietnam." World Development 64 (2014): 384-94. doi:10.2139/ssrn.2524146.

71 Tatarski, Michael. "A Vital Mangrove Forest Hidden in Vietnam's Largest City Could Be at Risk." Mongabay Environmental News. June 02, 2020. Accessed November 21, 2020. https://news.mongabay.com/2020/04/a-vital-mangrove-forest-hidden-in-vietnams-largestcity-could-be-at-risk/.

72 State of Water : Vietnam. Accessed November 21, 2020. http://www.wepadb.net/policies/state/vietnam/surface.htm.

${ }^{73}$ Shiva, Vandana. "'Miracle Seeds' and the Destruction of Genetic Diversity." In The Violence of the Green Revolution: Third World Agriculture, Ecology, and Politics, 61-102. University Press of Kentucky, 2016. Accessed November 21, 2020. http://www.jstor.org/stable/j.ctt19dzdcp.6.

74 Soong, Jennifer, "Soil Fertility and Changes in Fertilizer Use for Intensive Rice Cultivation in the Red River Delta and Mekong Delta of Vietnam" (2006).Independent Study Project (ISP) Collection. 340. https://digitalcollections.sit.edu/isp_collection/340

75 "Fertiliser Imports on the Rise." Khmer Times. May 09, 2020. Accessed November 21, 2020. https://www.khmertimeskh.com/50721495/fertiliser-imports-on-the-rise/.

${ }^{76}$ Ngoc, Bich. "Vietnam Bans Cancer-causing Herbicides following Roundup Verdict VnExpress International." VnExpress International - Latest News, Business, Travel and Analysis from Vietnam. April 11, 2019. Accessed November 21, 2020. https://e.vnexpress.net/news/news/vietnam-bans-cancer-causing-herbicides-followingroundup-verdict-3908046.html.

77 Thang, Tran Toan. "Fertilizers in Vietnam." ReSAKSS Asia. November 2014. http://ebrary.ifpri.org/utils/getfile/collection/p15738coll2/id/128880/filename/129091.pd.

${ }^{78}$ Kamienski, Lukasz. "The Drugs That Built a Super Soldier." The Atlantic. May 03, 2016. Accessed November 18, 2020. https://www.theatlantic.com/health/archive/2016/04/thedrugs-that-built-a-super-soldier/477183/. 
${ }^{79}$ Turse, Nick. "Rape Was Rampant During the Vietnam War. Why Doesn't US History Remember This?" Mother Jones. March 19, 2013. Accessed November 21, 2020. https://www.motherjones.com/politics/2013/03/rape-wartime-vietnam/.

${ }^{80}$ Taft, Casey T., Robin P. Weatherill, Halley E. Woodward, Lavinia A. Pinto, Laura E. Watkins, Mark W. Miller, and Rachel Dekel. 2009. "Intimate Partner and General Aggression Perpetration among Combat Veterans Presenting to a Posttraumatic Stress Disorder Clinic." American Journal of Orthopsychiatry 79 (4) (10): 461-468. doi:http://dx.doi.org.proxy.lib.pdx.edu/10.1037/a0016657. http://stats.lib.pdx.edu/proxy.php?url=http://search.proquest.com.proxy.lib.pdx.edu/docvi ew/1038622374? accountid=13265.

${ }^{81}$ Hendry, Sharon. "The Vietnamese Women Whose Mothers Were Raped in Wartime Seek Justice for a Lifetime of Pain and Prejudice." The Independent. September 13, 2017. Accessed November 21, 2020. https://www.independent.co.uk/news/world/asia/vietnamwar-women-seek-justice-mothers-raped-south-korean-soldiers-war-untold-storiesa7940846.html.

${ }^{82}$ Banerji, Angana, et al. "Asian Women at Work" The Rising Rate of Women Participating in Vietnam's Labor Force - IMF Finance \& Development Magazine | September 2018, Sept. 2018, www.imf.org/external/pubs/ft/fandd/2018/09/female-labor-forceparticipation-in-vietnam-banerji.htm.

${ }^{83}$ Teerawichitchainan, Bussarawan, Knodel, John, Vu, Manh Loi, \& Vu, Tuan Huy.(2009). Gender Division of Household Labor in Vietnam: Cohort Trends and Regional Variations. Paper presented at the American Sociological Association 104th Annual Meeting (August 2009); and Population Association of America Annual Meeting (May 2009), San Francisco, CA; Detroit.

${ }^{84}$ Pham, Phuong, Philippe Doneys, and Donna L. Doane. "Changing Livelihoods, Gender Roles and Gender Hierarchies: The Impact of Climate, Regulatory and Socio-economic Changes on Women and Men in a Co Tu Community in Vietnam." Womens Studies International Forum 54 (2016): 48-56. doi:10.1016/j.wsif.2015.10.001.

${ }^{85} \mathrm{Nga}$, Minh. "Two in Three Vietnamese Women Suffer Domestic Abuse - VnExpress International." VnExpress International - Latest News, Business, Travel and Analysis from Vietnam. July 14, 2020. Accessed November 21, 2020. https://e.vnexpress.net/news/news/two-in-three-vietnamese-women-suffer-domesticabuse-4130328.html.

${ }^{86}$ Team, The ASEAN Post. "'It's Your Fault!" - Domestic Abuse in Cambodia." The ASEAN Post. July 09, 2019. Accessed November 21, 2020. https://theaseanpost.com/article/itsyour-fault-domestic-abuse-cambodia.

${ }^{87}$ Yoshioka, Marianne, and Quynh Dang. "Asian Family Violence Report." Asian Task Force Against Domestic Violence, Inc., November 2000.

https://www.atask.org/site/images/pdf/asianfamilyviolencereport.pdf. 
${ }^{88}$ Owen, Taylor, and Ben Kiernan. "Bombs over Cambodia." The Walrus. October 2006. http://gsp.yale.edu/sites/default/files/walrus_cambodiabombing_oct06.pdf.

${ }^{89}$ Morris, Brett S. "Nixon and the Cambodian Genocide." Jacobin. April 27, 2015. Accessed November 21, 2020. https://www.jacobinmag.com/2015/04/khmer-rouge-cambodiangenocide-united-states/.

${ }^{90}$ Duong, Liai. "Racial Discrimination in the Cambodian Genocide." Genocide Studies Program, 2006. Yale.

91 “AEIR Data Catalogue.” Asia Regional Integration Center, aric.adb.org/fta-country.

92 Jennings, Ralph. "Vietnam Promises Big Privatization Push For 2019, But Reality May Fall Short." Forbes. December 31, 2018. Accessed November 21, 2020. https://www.forbes.com/sites/ralphjennings/2018/12/30/vietnams-promises-bigprivatization-push-for-2019-but-reality-may-fall-short/?sh=5f9c11bd2c51.

${ }^{93}$ Heberle Renée. Feminist Interpretations of Theodor Adorno. Pennsylvania State University Press, 2006. 